\title{
Bank integration and co-movements across housing markets
}

Article

Accepted Version

Milcheva, S. and Zhu, B. (2016) Bank integration and comovements across housing markets. Journal of Banking \& Finance, 72 (Supplement). S148-S171. ISSN 0378-4266 doi: https://doi.org/10.1016/j.jbankfin.2015.07.002 Available at https://centaur.reading.ac.uk/40764/

It is advisable to refer to the publisher's version if you intend to cite from the work. See Guidance on citing.

To link to this article DOI: http://dx.doi.org/10.1016/j.jbankfin.2015.07.002

Publisher: Elsevier

All outputs in CentAUR are protected by Intellectual Property Rights law, including copyright law. Copyright and IPR is retained by the creators or other copyright holders. Terms and conditions for use of this material are defined in the End User Agreement.

\section{www.reading.ac.uk/centaur}

\section{CentAUR}

Central Archive at the University of Reading

Reading's research outputs online 


\title{
Bank Integration and Co-movements across Housing Markets ${ }^{\diamond}$
}

\author{
STANIMIRA MILCHEVA ${ }^{*}$ AND BING ZHU ${ }^{* *}$
}

\begin{abstract}
This paper investigates whether bank integration measured by cross-border bank flows can capture the co-movements across housing markets in developed countries by using a spatial dynamic panel model. The transmission can occur through a global banking channel in which global banks intermediate wholesale funding to local banks. Changes in financial conditions are passed across borders through the banks' balance-sheet exposure to credit, currency, maturity, and funding risks resulting in house price spillovers. While controlling for country-level and global factors, we find significant co-movement across housing markets of countries with proportionally high bank integration. Bank integration can better capture house price comovements than other measures of economic integration. Once we account for bank exposure, other spatial linkages traditionally used to account for return co-movements across region - such as trade, foreign direct investment, portfolio investment, geographic proximity, etc. - become insignificant. Moreover, we find that the co-movement across housing markets decreases for countries with less developed mortgage markets characterized by fixed mortgage rate contracts, low limits of loan-to-value ratios and no mortgage equity withdrawal.
\end{abstract}

JEL Classifications: C23, G15, F36, R3

Keywords: House prices, Bank capital flows, Bank integration, Dynamic spatial panel model, Global banking channel, Mortgage market development

\footnotetext{
$\checkmark$ We want to thank to the editor and two anonymous referees, as well as the participants of the International Finance and Banking Society Conference, the ReCapNet real estate symposium, the American Real Estate and Urban Economics National Meeting, the American Real Estate and Urban Economics International Meeting, the European Real Estate Society Conference, the University of Lund research seminar, and the University of Regensburg research seminar. We are grateful to Wayne R. Archer, Shaun Bond, Yongheng Deng, Martin Hoesli, Gabriel Lee, Philip Lane, Ronan Lyons, Jan Mutl, Liang Peng, S. E. Ong, Margarita Rubio, and Rolf Tschernig for useful comments.

*University of Reading, Henley Business School, Whiteknights Campus, RG5 5UD, Reading, UK. Email: s.milcheva@reading.ac.uk, phone: +44 (0) 1183787650.

*** University of Regensburg, Faculty of Economics, bing.zhu@wiwi.uni-regensburg.de.
} 


\section{Introduction}

Although real estate has been regarded as a highly illiquid asset, co-movements in house prices across different countries exist, as has become apparent during the recent financial crisis originating in the US subprime mortgage market. It is thus necessary to explore in more depth the linkages across the housing markets given the important role housing plays in the real economy. ${ }^{1}$ Housing wealth accounts for more than half of a household's net wealth in developed countries; it exposes individuals to changes in the underlying value of their property assets and affects their spending decisions. Moreover, housing serves as collateral in mortgage borrowing making leveraged households even more dependent on the value of their property. Given that the financial markets are imperfect, the interactions between the housing markets and the macroeconomy can be amplified through channels such as the financial accelerator mechanism (Iacoviello, 2005). It is thus important to assess the co-movements across housing markets through the lens of the underlying channels connecting those markets. While the majority of the research assesses the size of the spillover effects in different periods ${ }^{2}$, there is little research on the channels behind the co-movements across the housing markets. Our paper contributes to the existing literature by providing a different perspective in assessing housing market interdependences. We apply a spatial econometrics framework, traditionally used in geography and urban studies, to assess the role of bank integration in capturing the linkages across housing markets. The reason for this is that through spatial models we can directly capture the factors

\footnotetext{
${ }^{1}$ Recently Tong and Wei (2011), Beltratti and Stulz (2012), Calomiris et al. (2012), Bekaert et al. (2014), etc. assess the linkages on the financial markets.

${ }^{2}$ A series of studies (i.e., Hirata et al., 2013; Cesa-Bianchi, 2013; Eickmeier et al., 2014) show evidence of increased synchronization of the housing cycles among developed countries during the last few decades which may reflect the increase in financial and trade integration.
} 
behind the linkages on the housing markets. Furthermore, we assess whether the co-movements on the housing markets can be weakened or strengthened depending on the degree of mortgage market flexibility in each country.

In order to account for the spatial linkages we need to define our measure of contiguity. The majority of the studies use the geographic proximity between regions as a measure of the spatial dependence. The rationale is that the spillovers across regions can be explained by factors, such as migration (Gupta and Miller, 2012), wealth externalities (Clapp et al., 1995; Miao et al., 2011), infrastructure improvements (Holly et al., 2011), etc. However, recent research (FernandezAvilez et al., 2012; Asgharian et al., 2013) shows that the physical distance may not be the best way to account for spatial co-movements. Indeed, measures of 'economic distance' have been introduced in an attempt to deal with the cross-sectional dependence of economic variables (see Conley and Topa, 2002; Pesaran et al., 2004). Zhu et al. (2013) show that the economic closeness is an important driver of the co-movements in house prices across US regions. Asgharian et al. (2013) compare several measures of spatial proximity to find that bilateral trade best captures the international co-movements on the stock markets. Considering the financial innovations and the deregulation of the financial markets during the Great Moderation, it is thus important to go beyond the traditional measures of spatial co-movement and to account for the interconnectivity of the financial markets. Since real estate is a highly capital-intensive asset class, an important driver of the spillovers across the housing markets could stem from the exposure of banks to funding from abroad, given that banks are still the predominant source of mortgage lending in the majority of the countries. Figure 1 reveals an interesting observation in this regard. It shows the relationship between bilateral bank exposure and housing market integration for each pair in a sample of 17 developed countries. The bank exposure measures the sum of total banks' foreign assets and liabilities of one country with another country. The figure reveals that the higher the 
bank exposure between two countries the higher the integration and hence the co-movement of their housing markets. ${ }^{3}$

\section{Figure 1: Bilateral bank exposure and housing market integration}

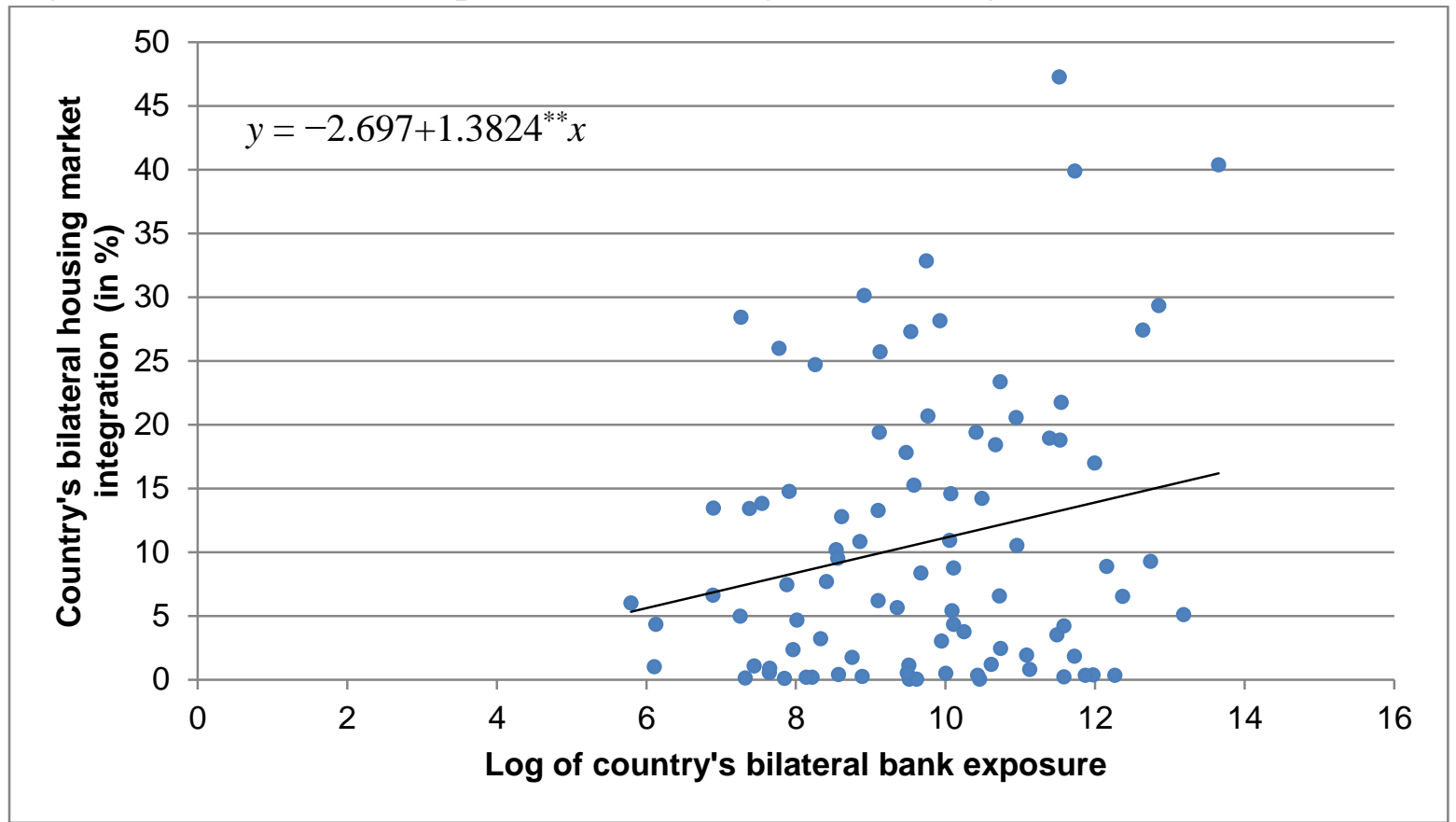

Note: Country's bilateral bank exposure is based on the average sum of foreign bank flows (assets and liabilities) of one country with another country. The country's bilateral housing market integration is the R-square of an OLS regression of the housing return of one country on the housing return of its counterparty. This value is equivalent to the squared correlation of significant monthly growth rates in house prices for each country pair in our sample. It is regarded as a measure of integration or co-movement between two countries (Pukthuanthong and Roll, 2009). Data used for 17 advanced economies (see Section 4). Data for bank flows is from the Bank of International Settlements. Data for house prices is summarized in Table A.1. The slope of the fitted line is significant at 5\%.

The transmission of housing market spillovers across countries can occur through a 'global banking channel'. Ivashina et al. (2012) and Bruno and Shin (2014) present theoretical frameworks of this transmission channel and assess the lending and borrowing behavior of global banks. Given the slow growth in deposits, local banks finance mortgage credit growth through short-term borrowing on the international interbank markets. Global banks engage in wholesale funding, most of it denominated in US dollars, distributing the money to the local banks through the interbank market. A study by the Bank for International Settlements (BIS) (2010) describes

\footnotetext{
${ }^{3}$ This relationship is significant at the $5 \%$ confidence level.
} 
how the US branches and subsidiaries of global banks borrow funds from the US money market and then channel those funds to their headquarters. Through the global banking channel, fluctuations in financial conditions in one country can be passed through to their counterparties through cross-border bank claims, capturing a variety of financial risks. On the asset side, banks can face higher credit risk partially reflecting an increase in leverage (Bank of England, 2013). On the liability side, a funding risk is directly linked to the economic situation in the foreign countries since banks not only lend to foreign borrowers, they also rely heavily on funding from abroad, especially from other banks. Indeed, since banks borrow on the global wholesale market, most liabilities are short-term positions in foreign currency while most assets are long-term positions in local currency, thus increasing the maturity mismatch and the exchange rate risk. Given the above considerations, we use the exposure of banks in one country to bank inflows and outflows from other countries to determine our measure of spatial dependence and call it bank integration. As a result, countries with stronger bank integration may observe stronger housing market co-movements through variations in the supply of mortgage credit. We also compare our measure of connectedness against alternative measures of spatial dependence, such as geographic proximity, trade, foreign direct investment (FDI), portfolio investment and so on.

The results reveal that housing markets in countries with stronger bilateral bank exposure experience significantly stronger co-movement relative to the rest of the countries. Indeed, bank integration can better capture housing market co-movements than other measures of spatial linkages, which become insignificant once we account for bank exposure. Moreover, we find that the co-movement across housing markets decreases for countries with less developed mortgage markets where the prevailing type of mortgage rates are fixed, loan-to-value (LTV) ratios are low and mortgage equity withdrawal (MEW) is not available. 


\section{Literature review}

The degree of dependence among stock markets internationally has been extensively studied using different approaches (Karolyi and Stulz, 1996; Asgharian and Bengtsson, 2006; Asgharian and Nossman, 2011; Milcheva, 2013). However, there is little research that tries to assess the comovement across the housing markets, as they have been regarded as more heterogeneous and illiquid. Vansteenkiste and Hiebert (2011) and Cesa-Bianchi (2013) show evidence for house price spillovers in the euro area using a Global Vector Autoregressive (GVAR) model. However, the effect of a country-specific house price shock on housing prices in the remaining euro area countries is of a relatively low magnitude (Vansteenkiste and Hiebert, 2011). While most of the existing studies have focussed on the degree of dependence across housing markets, little research has been conducted on the linkages connecting the asset markets. Holly et al. (2011) analyze the spatial and temporal diffusion of house price shocks across UK regions. They find that a shock to London's house prices has a significant contemporaneous effect on all other regions, with the size of the effect depending on the commuting distance of the region from London. However, apart from the geographic proximity used to capture spatial dependence across markets, there might be other factors driving the co-movements of asset prices. Fernandez-Aviles et al. (2012) and Asgharian et al. (2013) analyze spatial dependencies across stock markets using measures of economic distance between the countries. Fernandez-Aviles et al. (2012) find that the co-movement across the stock markets is not driven by geographic distance but rather buy the FDI proximity of those markets. Asgharian et al. (2013) also account for trade, inflation, exchange rate and interest rate convergence across countries. They estimate a spatial panel model for a large sample of countries from 1995 to 2011 in order to compare different spatial linkages, and find that the most important driver of the co-movements in stock markets is bilateral trade. 
The effect of gross capital flows on the domestic economy, in general, and especially of those channelled through the banking sector, has recently received attention from researchers (Borio and Disyatat, 2011; Lane and Pels, 2011; Forbes and Warnock, 2012; Gourinchas and Obstfeld, 2012; Obstfeld, 2012a, 2012b; Schularick and Taylor, 2012; Shin, 2012; Rey, 2013). The strong credit growth in many developed countries prior to the crisis could have been driven by the increased flow of capital from foreign banks, meaning that these countries were more prone to variations in the international credit markets (Allen et al., 2011). Recent research (McGuire and Tarashev, 2007; Cetorelli and Goldberg, 2011, 2012b; Lane and McQuade, 2014; Bruno and Shin, 2014) argues that the international banking system is becoming a more important conduit for the transfer of capital across countries. Lane and McQuade (2014) propose that there could be a systematic relation between international capital flows and domestic credit growth. They find that net foreign debt flows have a significant impact on credit growth. Altunbas et al. (2009) and Cetorelli and Goldberg (2011) argue that the increase in domestic credit has been facilitated by the large growth in cross-border interbank lending, the opening of international subsidiaries and the emergence of financial derivatives. According to Shin (2012), global foreign banks increasingly engaged in the US shadow banking system prior to the crisis, getting funding through the US wholesale market. Cetorelli and Goldberg (2012a, 2012b) use bank-level data to provide evidence of the importance of cross-border internal capital markets in the reallocation of funds within global banking organizations and the propagation of local shocks across borders. Kapan and Minoiu (2013) use loan data to exploit variations in banks' reliance on wholesale funding and show that the supply of bank credit reduces for institutions with high wholesale funding exposure during periods of market freeze. Landier et al. (2013) show that house price synchronisation across US states has increased, and contribute this finding to the increase in the 
integration of the US banking market due to the ongoing deregulation.

The growth of foreign bank exposure can lead to an increase in asset prices either directly, by pushing up the demand for domestic assets, or indirectly, by facilitating more rapid credit growth. A number of studies (Aizenman and Jinjarak, 2009; Beltratti and Morana, 2010; Bagliano and Morana, 2012; Mendicino and Punzi, 2014) have tried to explain the linkages between capital flows and house prices. Peek and Rosengren (2000) show that an increase in financial integration can enhance synchronization in the real estate markets and economic activity due to the propagation of credit supply shocks across the connected markets. ${ }^{4}$ Loutskina and Strahan (2012) show that an increase in financial integration across US regions following an expansion of bank branch networks leads to stronger output sensitivity to local house price shocks. Landier et al. (2013) show that financial integration across US states, as measured by the emergence of large banks, is an important driver of house price growth correlation and can explain up to one third of it. Bagliano and Morana (2012) find that the international transmission of financial shocks takes place through the US house price dynamics. Beltratti and Morana (2010) also show that USspecific financial disturbances are an important driver of the fluctuations in real house prices across countries. Asgharian and Nossman (2011) find that the risk spillover from the US stock market contributes to jumps of returns on the European equity markets. Interconnected banking sectors can serve as a transmission channel of liquidity shocks across borders. Schnabl (2012)

\footnotetext{
${ }^{4}$ Peek and Rosengren (2000) use the Japanese banking crisis as a natural experiment to explore the effect of an exogenous supply shock to the US credit market on construction activity in real estate and output in the US. The shock is transmitted to the US market through the interconnectivity of the financial markets of both countries due to the high Japanese bank penetration in US. The findings reveal that financial integration between countries enables the cross-country transmission of country-specific shocks.
} 
shows that the Russian default crisis in 1998, a country-specific event, had negative effects on Peruvian businesses through the global banks operating in both countries following a reduction in their inter-bank lending. Sa et al. (2013) show that capital inflows in Organisation for Economic Co-operation and Development (OECD) member countries lead to a significant increase in credit and house prices, but the effect is stronger in countries with more developed mortgage markets and in countries where securitisation is allowed. Securitisation could also enhance the dependence of mortgage credit supply on variations in local housing markets due to variations in the market value of the collateral (Loutskina and Strahan, 2011). Rajan et al. (2010) explain this by the increased dependence of lenders on public signals, such as LTV ratios, as opposed to private information.

\section{Econometric modelling}

\subsection{The spatial dynamic panel model}

We analyze the co-movements across housing markets using a spatial dynamic panel model. By incorporating spatial terms into a panel setting we can explain the 'time-space dynamics' in the variation in housing returns at one location by the variation in housing returns at other locations. The model is presented in a matrix form as:

$Y_{t}=\rho W_{t} Y_{t}+\varphi Y_{t-1}+X_{t} \beta+W_{t} X_{t} \lambda+Z_{t} \gamma+D \alpha+e_{t}$

Here $Y_{t}$ denotes an $N \times 1$ vector of dependent variables, with $Y_{t}=\left(y_{1, t}, y_{2, t}, \ldots, y_{N, t}\right)^{\prime}$ where $y_{i, t}$ stands for the house price growth or housing return in country $i$ in period $t$, with $i=1, \ldots, N$ and $t$ 
$=1, \ldots, T . Y_{t-1}$ is the vector of lagged housing returns. $\varphi$ is the coefficient for lagged endogenous variable. $W_{t}$ is the standardized non-stochastic spatial dependence weight matrix with zero diagonal terms and non-zero off-diagonal elements. Each off-diagonal element captures the bilateral cross-country correlation. It is important to notice that when constructing the weight matrix, we use time-varying weights since shifts in the weights can have implications on the estimated coefficients. $W_{t} Y_{t}$ captures the contemporaneous return co-movements across the $N$ countries, and $\rho$ is the spatial autoregressive parameter. The spatial dependence of housing returns is captured by the bilateral bank foreign exposure between each of the two markets presented in the next section. $X_{t}$ is an $N \times K$ matrix that controls for country-specific variables, such as inflation, output, etc. $\beta$ is a $K \times 1$ coefficient vector, with $K$ being the number of countryspecific variables, which measures the effect of changes in the country-specific variables on housing returns in the respective country. $W_{t} X_{t}$ captures the impact of the foreign variables, such as inflation, output, etc., averaged across countries using a spatial weight matrix. $\lambda$ is a $K \times 1$ coefficient vector that captures the effect of changes in the foreign country-specific variables on housing returns in the domestic country. We also account for variations on the global markets in order to control for return co-movements that are not explained by country-specific variations. Hence, these variables would take the same value for all countries. They are captured by the $Z_{t}$ matrix, including two global variables presented in Section 4. $D$ is an $N \times 1$ vector, including $N$ - 1 country dummy variables and a constant term. Since we use time-varying weights, we use country dummy variables instead of country fixed effects. The dummy variables capture the remaining time-invariant individual market characteristics, such as mortgage market characteristics, property evaluation methods and others, which are not accounted for by our country-specific variables. $e_{t}$ is an $N \times 1$ vector of country independent disturbances in period $t$, 
and the variance-covariance matrix of $e_{t}$ is $\Omega_{e}=\sigma^{2} I_{N T}$.

The model in Equation (1) is a restricted form of the more general, feasible dynamic Durbin model given by $Y_{t}=\rho W_{t} Y_{t}+\varphi Y_{t-1}+\eta W_{t-1} Y_{t-1}+X_{t} \beta+W_{t} X_{t} \lambda+Z_{t} \gamma+D \alpha+e_{t}$. Elhorst (2014) suggests the use of it in order to fully capture the time-space dynamics. However, the Durbin model suffers from the identification problem and therefore needs restrictions on the parameters. Following Elhorst (2014), we therefore restrict the spatial lagged parameter, $\eta$, to be equal to zero, as it does not exclude any of the above spatial effects contained in the dynamic spatial Durbin model. Other restrictions, such as $\rho=0$ or $\varphi=0$, set restrictions on the short-term indirect spillover effects and the long-term effects, respectively. Compared with other spatial models, our model can capture the dependencies not only with directly connected countries (direct spillovers, which only affect neighbors, as in Elhorst, 2014), but also dependencies with countries that are not directly exposed to each other (indirect spillovers, which affect the neighbors' neighbors). In addition, through the inclusion of lagged variables, the dynamic Durbin model allows for the spatial dependence not only to affect housing returns in the same period (short-term spillover effects, as in Elhorst, 2014) but also to be transmitted to future periods (long-term spillover effects).

The model in Equation (1) is solved by maximum likelihood estimation. We follow Yu et al. (2008), so that the concentrated likelihood function is given by ${ }^{5}$ :

$L L=\sum_{t=1}^{T} \ln \left|I_{N}-\hat{\rho} W_{t}\right|-\frac{N T}{2} \ln \left(2 \pi \hat{\sigma}^{2}\right)-\frac{\sum_{t=1}^{T} \hat{e}_{t}^{\prime} \hat{e}_{t}}{2 \hat{\sigma}^{2}}$,

\footnotetext{
${ }^{5}$ The estimations are based on a Matlab toolbox provided by LeSage (2010) at http://www.spatial-econometrics.com.
} 
with

$\hat{e}_{t}=Y_{t}-\hat{\rho} W_{t} Y_{t}-\hat{\varphi} Y_{t-1}-X_{t} \hat{\beta}-W_{t} X_{t} \hat{\lambda}-Z_{t} \hat{\gamma}-D \hat{\alpha}$

It should be noted that in the above model the parameters associated with the country-specific variables $(\beta)$ capture only the average immediate effects of changes in the explanatory variables on the returns of that country, and do not account for direct and indirect spillover effects. The coefficients that capture those effects are called the marginal coefficients (Kelejian et al., 2006) ${ }^{6}$. The marginal effects thus need to be calculated. Assuming that the infinite sums are well-defined, by continuous substitution, Equation (1) can be represented as:

$Y_{t}=\sum_{p=0}^{\infty} A_{t-p}^{p} V_{t-p}\left(X_{t-p} \beta+W_{t-p} X_{t-p} \lambda+Z_{t-p} \gamma+D \alpha+e_{t-p}\right)$

where $V_{t}=\left(I-\rho W_{t}\right)^{-1}$ and $A_{t}=\varphi\left(I-\rho W_{t}\right)^{-1}$. Since $\left(I-\rho W_{t}\right)^{-1}=I+\rho W_{t}+\rho^{2} W_{t}^{2}+\rho^{3} W_{t}^{3}+\cdots$, Equation (1) implies a spatial multiplier effect (Anselin, 2006; LeSage and Pace, 2009). Any changes in the variables or unexpected shocks in one country will also affect the remaining countries through the spatial relationship among the countries. Not only do the first order 'neighbors', $\rho W_{t}$, get affected (the direct spillover effect), but the 'neighbor's neighbors' are also impacted through that spatial multiplier effect through $\rho^{2} W_{t}^{2}, \rho^{3} W_{t}^{3}$, etc. (the indirect spillover

\footnotetext{
${ }^{6}$ Similarly, the values of the parameter vector $\lambda$ should be interpreted as immediate effects of changes in the foreign country variables on the returns in the domestic country.
} 
effect). In the end, the change can have a feedback effect on the country of origin of the shock.

For the $k^{\text {th }}$ row of $X_{t}$, we define $S_{k, t}=V_{t}\left(I \beta_{k}+W_{t} \lambda_{k}\right)$. The average marginal effect of $X_{k}$ on housing returns on the domestic market is:

$$
M_{k, \text { domestic }}=\frac{1}{T N} \sum_{t=1}^{T} \sum_{i=1}^{N} S_{i i, k, t}
$$

and the average marginal effect on the other markets is:

$$
M_{k, \text { other }}=\frac{\sum_{t=1}^{T} \sum_{i=1}^{N} \sum_{j=1, j \neq i}^{N} S_{i j, k, t}}{T N(N-1)}
$$

Following a one unit housing return shock in country 1, the average unscaled response of the housing returns in all countries in the subsequent period $P$ can be calculated as (Pesaran and Shin, 1998):

$$
\left[\begin{array}{c}
\psi_{1,1, P} \\
\psi_{1,2, P} \\
\vdots \\
\psi_{1, N, P}
\end{array}\right]=\frac{1}{T} \sum_{1}^{T} \sum_{p=0}^{P} A_{t+p}^{P} V_{t+p} \frac{\Omega_{e}}{\sigma_{1}^{2}}\left[\begin{array}{c}
1 \\
0 \\
\vdots \\
0
\end{array}\right]
$$

where $\sigma_{1}^{2}$ is the variance of country $1 . \psi_{1, j, P}$ is the response of the housing market in the $j$ th country to the shock in the country 1 . Since $\Omega_{e}$ is assumed to be a diagonal matrix - i.e. the error terms are independent from each other - the cross-border transmission of a country-specific 
shock entirely occurs through the spatial structure of $V$. This differs from time series models like VAR models, where the cross-sectional transmission of shocks largely depends on the covariance matrix of the error terms. Based on Equation (7), the average spillover effect of a one unit housing shock in the $i$ th country in period $P$ is:

$\psi_{i, P}^{i m p}=\frac{1}{N-1} \sum_{j=1, j \neq i}^{N} \psi_{i, j, P}$

The average response of the $i$ th country in period $P$ to a foreign country shock is:

$\psi_{i, P}^{r e s}=\frac{1}{N-1} \sum_{j=1, j \neq i}^{N} \psi_{j, i, P}$

\subsection{Spatial weight matrix}

In spatial econometrics, the spatial weight matrix needs to be specified ad hoc. In this paper, we want to assess the impact of bank integration as a measure of proximity between housing returns across countries by using cross-border bank flows. Banks may grow their foreign claims portfolio through two channels: they can establish affiliates in different countries and extend claims locally through their branches and subsidiaries in these countries; or they can extend cross-border claims by financing and booking the claims from outside the recipient or host countries. Both types of claims are reflected in the consolidated bank flows from the Bank for International Settlements (BIS) used in this analysis. Figure 2 shows that bank foreign claims with both developed and developing countries have increased dramatically in the last decade prior to the financial crisis, followed by a redistribution of bank flows away from developed countries towards developing countries starting in 2009. Prior to the crisis, the level of bank flows towards developed countries 
was larger than that towards developing countries. Lane and Milesi-Ferretti (2008) also show that the cross-border positions among advanced economies grew more quickly than among emerging countries, attributing this to factors associated with financial market development. However, in 2010, exposure to developing countries took over foreign exposure towards developed countries and has kept increasing since then. Foreign claims of banks to developed countries have remained relatively constant since 2010 . We can see that at the end of 2013 their level was comparable to that at the end of 2006.

\section{Figure 2: Foreign claims of all reporting banks to developed versus developing countries}

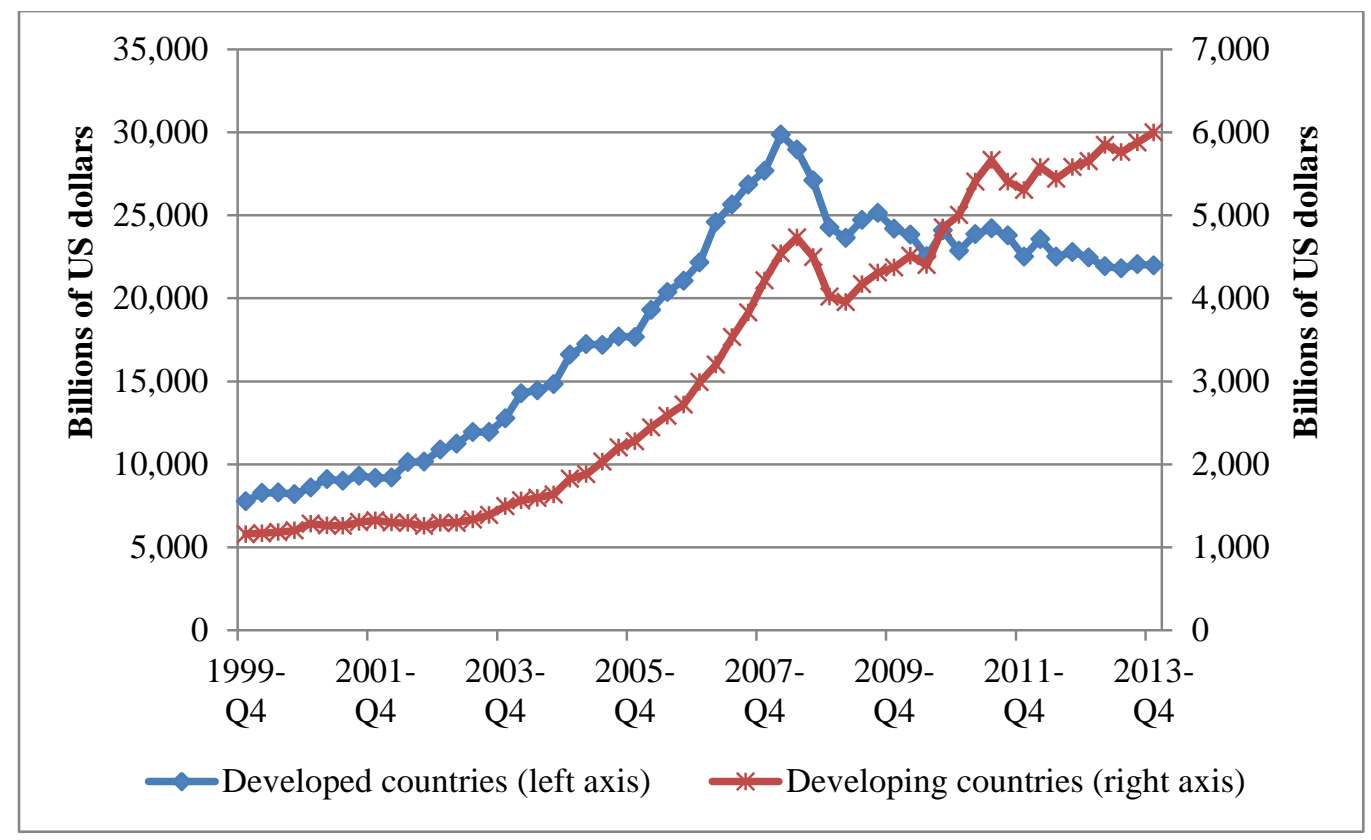

Source: BIS

Note: Consolidated statistics, immediate borrower basis, based on the BIS Banking Statistics in Table 9A:S.

The weight matrix is constructed in two steps. Firstly, we calculate the ratio of the bank claims between two countries to the sum of total bank claims of each of the two countries:

$$
F_{i, j, t}^{\text {bank }}=\frac{\operatorname{Claim}_{i, j, t}+\text { Claim }_{j, i, t}}{\sum_{k} \operatorname{Claim}_{i, k, t}+\sum_{k} \operatorname{Claim}_{k, i, t}},
$$


where Claim $_{i, j, t}$ stands for the bank claim from country $i$ to country $j . F_{i, j, t}^{\text {bank }}$ measures the importance of country $j$ for country $i$ in terms of bank integration and $k=1, \ldots, j, \ldots, N$. Secondly, we construct a contiguity matrix with elements that indicate, for any country pair, how contiguous market $j$ is to market $i$, based on the degree of bank integration between those two countries:

$$
C_{i, j, t}=1-\frac{\max _{j, t} F_{i, j, t}-F_{i, j, t}}{\max _{j, t} F_{i, j, t}-\min _{j, t} F_{i, j, t}} .
$$

According to Asgharian et al. (2013), this measurement ensures that all elements of the contiguity matrix lie between zero and one, with $C_{i, j, t}=1$ if country $j$ has the shortest distance (i.e., highest integration) to country $i$ and $C_{i, j, t}=0$ if country $j$ has the longest distance (i.e., lowest integration) to country $i$. While constructing the weight matrix accounting only for the first step will leave the matrix symmetrical, the second step assures that the matrix is not necessarily symmetric. It means that even if country $i$ is an important neighbor for country $j$ (i.e., $C_{j, i, t}$ is close to one), country $j$ may not be important for country $i$ (i.e., $C_{i, j, t}$ is close to zero). The weight matrix is then obtained from the contiguity matrix through row standardisation, such that for each $i$, the sum of the elements in the weight matrix should be equal to one: $\sum_{j, t} w_{i, j, t}=1$.

\subsection{Robustness analysis}

In this paper, we conduct a series of robustness checks. Firstly, we use the bank flow weight matrix, applying an alternative method of weight calculation based either on liabilities or on assets. We also estimate Equation (1) using a time-unvarying weight matrix as well as including additional variables that capture mortgage market variations. Secondly, we investigate the 
capability of the bank flow matrix to identify 'neighbors' and 'non-neighbors' by grouping together countries that have the strongest or the weakest bank integration respectively. We thereby assess whether the spatial dependence is merely caused by unobserved global common factors or by banking linkages across the countries. We also assess the appropriateness of our measure of bank integration by including a randomly generated weight matrix. Thirdly, the multicountry spatial links may also be associated with other drivers, such as interest rate similarity, similarity in inflation rates, geographic distance, trade proximity, foreign direct investment, portfolio investment proximity and so on. Therefore, we want to assess not only whether bank integration is important, but also whether it can substantially add information beyond the linkages mentioned above.

\subsubsection{Alternative weight definition}

Since an increase in spatial correlations resulting from increased bank integration can be associated with either asset or liability risks, we want to separately assess the financial linkages stemming from each of those channels. We use the same bilateral bank claims data for constructing the alternative weights. The asset-side exposure matrix is calculated from the share

of claims of country $i$ to country $j$ divided by total bank claims of country $i$ to all countries in the sample:

$$
F_{i, j, t}^{\text {asset }}=\frac{\text { Claim }_{i, j, t}}{\sum_{k} \operatorname{Claim}_{i, k, t}} .
$$

The liability-side exposure matrix is calculated from the share of liabilities of country $i$ to country $j$, divided by total liabilities of country $i$, or in terms of counterparty claims - claims of country $j$ 
to country $i$ divided by total bank claims of country $j$ to all countries in the sample:

$$
F_{i, j, t}^{\text {liability }}=\frac{\text { Claim }_{j, i, t}}{\sum_{k} \operatorname{Claim}_{j, k, t}} .
$$

\subsubsection{Economic significance}

Another issue is whether the bank flow matrix can really capture the dependence among international housing markets, or whether the significant coefficient is only due to unobserved global co-movement that is caused by global shocks. Therefore, we check whether the important neighbors of a country (the neighbors with a large weight) exhibit a stronger dependence with that country, compared to unimportant neighbors (the neighbors with a smaller weight). Following Asgharian et al. (2013), we create two weight matrices based on the cross-border bank flows. The first is the neighbor matrix and the other represents the non-neighbors. For each country $i, 50 \%$ of the remaining countries with the strongest financial integration are considered to be neighbors. The neighboring countries are captured in the matrix $C_{t}^{n b}$ with elements $C_{i, j, t}^{n b}=C_{i, j, t}$ if $C_{i, j, t} \geq$ median $_{j} C_{i, j, t}$ and zero otherwise. Similarly, the remaining $50 \%$ are the nonneighboring countries which are captured in $C_{t}^{n o n-n b}$ with elements $C_{i, j, t}^{n o n-n b}=C_{i, j, t}$ if $C_{i, j, t}<$ median $_{j} C_{i, j, t}$ and zero otherwise. Then $C_{t}^{n b}$ and $C_{t}^{n o n-n b}$ are row-standardized, and we obtain $W_{t}^{n b}$ and $W_{t}^{n o n-n b}$. We simultaneously include both weight matrices into one regression model in order to distinguish the spatial dependence between neighbors and non-neighbors. So the new model is given by: 
$Y_{t}=\left(\rho^{n b} W_{t}^{n b}+\rho^{n o n_{-} n b} W_{t}^{n o n_{-} n b}\right) Y_{t}+\varphi Y_{t-1}+X_{t} \beta+W_{t}^{n b} X_{t} \lambda^{n b}+W_{t}^{n o n_{-} n b} X_{t} \lambda^{n o n_{-} n b}$

$+Z_{t} \gamma+D \alpha+e_{t}$.

Furthermore, we conduct another robustness check. If global shocks are the predominant reason for the cross-country co-movement, the estimated coefficient $\rho$ can be very large, no matter what kind of weight matrix we choose. Therefore we add a randomly generated weight matrix into the regression to check whether the spatial dependence is caused by bank exposure or by common shocks:

$Y_{t}=\left(\rho^{\text {bank }} W_{t}^{\text {bank }}+\rho^{\text {random }} W_{t}^{\text {random }}\right) Y_{t}+\varphi Y_{t-1}+X_{t} \beta+W_{t}^{\text {bank }} X_{t} \lambda^{\text {bank }}+W_{t}^{\text {random }} X_{t} \lambda^{\text {random }}$

$+Z_{t} \gamma+D \alpha+e_{t}$

The regression is run 200 times. $\rho^{\text {random }}$ can be used to derive the confidence interval for the economic significance of $\rho$. Significant larger spatial coefficient for the bank flow matrix than for the random matrix can reveal significant co-movement effect without the influence from global shocks.

\subsubsection{Different linkages among housing markets internationally}

Previous literature on spatial modelling documents a variety of different linkages across markets. To account for other possible linkages across housing markets internationally, we estimate a model including a second spatial weight matrix next to the bank flow matrix. The idea of this exercise is to see if the presence of another spatial link among returns can weaken the impact of bank integration. The model with two weight matrices is given by: 
$Y_{t}=\left(\rho^{\text {bank }} W_{t}^{\text {bank }}+\rho^{\text {non_bank }} W_{t}^{\text {non_bank }}\right) Y_{t}+\varphi Y_{t-1}+X_{t} \beta+W_{t}^{\text {bank }} X_{t} \lambda^{\text {bank }}+W_{n, t}^{\text {non_bank }} X_{t} \lambda^{\text {non_bank }}$

$+Z_{t} \gamma+D \alpha+e_{t}$

where $W_{t}^{\text {bank }}$ stands for our measure of bank integration and $W_{t}^{\text {non_bank }}$ stands for the alternative weight matrix, the definition of which can be found below.

\section{Trade linkages}

Several papers (Beine et al., 2010; Wälti, 2010; Asgharian et al., 2013) argue that trade fosters business cycle synchronization across countries, thereby affecting the cross-country dependence of stock markets. The effect of trade on the housing market is not as straight forward as for the more liquid stock market. But similarly, if trade between two countries increases, it can expand the output of trading partners and income growth, thus leading to an increase in the comovements of housing markets. We calculate the importance of country $j$ for country $i$ by taking the trade between the two countries as a proportion of the total trade of country $i$ with all other countries:

$F_{i, j, t}^{\text {Trade }}=\frac{\operatorname{Export}_{i, j, t}+\text { Export }_{j, i, t}}{\sum_{k} \operatorname{Export}_{i, k, t}+\sum_{k} \operatorname{Export}_{k, i, t}}$.

\section{FDI linkages}

Another linkage that may capture the housing market dependence is the bilateral FDI. One category of FDI is foreign direct real estate investment. A pair of countries with larger bilateral FDI, especially larger bilateral real estate FDI, may be more heavily exposed to counterparty 
shocks than counties with smaller FDI. If FDI between two countries increases, house price comovements can increase due to stronger demand from foreign investors. While Chinn and Forbes (2004) do not find a significant impact of FDI for stock market co-movement, Asgharian et al. (2013) document significant FDI linkages among international stock markets. We calculate the importance of country $j$ for country $i$ by taking the FDI between the two countries as a proportion of the total FDI of country $i$ with all other countries:

$$
F_{i, j, t}^{F D I}=\frac{\text { Outward }_{i, j, t}+\text { Outward }_{j, i, t}}{\sum_{k} \text { Outward }_{i, k, t}+\sum_{k} \text { Outward }_{k, i, t}} .
$$

\section{Portfolio investment linkages}

Similar to FDI, portfolio investment can also capture housing co-movements. If portfolio investment between two countries increases, house price co-movements can increase due to stronger indirect demand from foreign investors through the purchase of real estate stocks or investment in equity funds. Previous studies use this measure in a GVAR context (Eickmeier and $\mathrm{Ng}, 2011$ ). We calculate the importance of country $j$ for country $i$ by taking the portfolio investment between the two countries as a proportion of the total portfolio investment of country $i$ with all other countries:

$$
F_{i, j, t}^{P F I}=\frac{\text { Outward }_{i, j, t}+\text { Outward }_{j, i, t}}{\sum_{k} \text { Outward }_{i, k, t}+\sum_{k} \text { Outward }_{k, i, t}} .
$$

\section{Openness similarity}


Instead of using the trade or investment linkages, we use a measure of openness from the Heritage Foundation, accounting for both trade and investment openness. For this purpose we take the average of the trade and the investment openness, which are sub-indices of the Index of Economic Freedom constructed by the Heritage Foundation. Trade freedom is defined as "the absence of tariff and non-tariff barriers that affect imports and exports of goods and services" (The Heritage Foundation, 2014). Investment freedom is determined by the number of restrictions on foreign investment, such as restrictions on real estate purchases, foreign exchange and capital controls, different national treatment of foreign investment, bureaucracy, expropriation of investment, etc. We calculate the openness proximity between two countries $i$ and $j$ as:

$F_{i, j, t}^{o p e n}=\mid$ Open $_{i, t}-$ Open $_{j, t} \mid$,

where $\mathrm{Open}_{i, t}$ is the openness score in country $i$ at period $t$.

\section{Inflation expectation divergence and deviation from purchasing power parity}

Under the existence of purchasing power parity (PPP), for each pair of countries that show a higher convergence of inflation, investors may decide to hedge against inflation by buying not only domestic assets, such as houses, but also assets from a country with a similar inflation rate (see Asgharian et al., 2013). As a consequence, this can lead to stronger housing market integration between these countries, driving up house prices. Inflation convergence is measured as the difference in inflation rates between country $i$ and $j$ adjusting for the deviations from the PPP such that: 


$$
F_{i, j, t}^{c p i}=\left|I N F L_{i, t}-I N F L_{j, t}-E_{t-1}\left(\frac{F X_{i, j, t}}{F X_{i, j, t-1}}-1\right)\right|,
$$

where $F X_{i, j, t}$ is the expected growth of the price of one unit of currency in country $j$ in terms of the currency in country $i$ and INFL is the inflation rate.

\section{Interest rate differential and deviation from interest rate parity}

The convergence in interest rates can also capture effects associated with stronger financial integration between countries. Marston (1997) has indeed used interest rate convergence to measure financial integration. By including the interest rate weighted matrix and bank flow weighted matrix in one regression we can observe which of each financial measure is actually driving house prices. We use the difference in the 3-month money market rate $(I R)$ between country $i$ and country $j$, and also account for fluctuations in exchange rates between the two countries adjusting for the deviations from the PPP, such that:

$$
F_{i, j, t}^{I R}=\left|I R_{i, t}-I R_{j, t}-E_{t-1}\left(\frac{F X_{i, j, t}}{F X_{i, j, t-1}}-1\right)\right| .
$$

\section{Geographic distance}

Finally, as is the case for real estate, geographic proximity can be an important driver for house price spillovers. One way for international shock transmission to occur is through migration. The geographic proximity can, however, also capture stronger trade and investment linkages which 
may be due to better information and familiarity with the neighbor country. We follow Asgharian et al. (2013) and measure the geographic proximity based on the distance between the capital cities of the two countries:

$F_{i, j, t}^{D}=D_{i, j, t}$

where $\mathrm{D}_{i, j, t}$ is the distance between capital city $i$ and $j$ in time $t$. In this paper, $\mathrm{D}_{i, j, t}$ is calculated based on the latitude and longitude of the two cities using the spherical law of cosines formula.

Similarly, as in the bank flow weight, the various alternative $F$ matrices are transformed to the corresponding $C$ matrix. So $C_{i, j, t}$ is defined as:

$C_{i, j, t}=1-\frac{\max _{j, t} F_{i, j, t}-F_{i, j, t}}{\max _{j, t} F_{i, j, t}-\min _{j, t} F_{i, j, t}}$,

in the case that $F$ is a measure of economic distance (e.g., trade, FDI) or

$C_{i, j, t}=1-\frac{F_{i, j, t}-\min _{j, t} F_{i, j, t}}{\max _{j, t} F_{i, j, t}-\min _{j, t} F_{i, j, t}}$,

in the case that $F$ is a measure of geographic distance.

\section{Data}

The sample of countries is restricted by the availability of house price data and includes the 
following 17 OECD countries: Australia, Austria, Belgium, Canada, Denmark, Finland, France, Germany, Greece, Ireland, Italy, the Netherlands, Spain, Sweden, Switzerland, UK and the US. ${ }^{7}$ The estimation period ranges from the first quarter of 1990 to the fourth quarter of 2012. The dependent variable is the quarterly log-difference of house prices (see Figure A.1). House price indices are collected from BIS and are based on data from national sources. More detailed information about the house price data is presented in Table A.1. For Greece, BIS data was not available; therefore, we use data from Oxford Economics. Data for UK and US is taken directly from the original source and not from BIS, although there are no major differences in the time series. Figure A.1 shows the quarter-over-quarter growth rate of house prices for the countries in the sample. We observe a similar trend in the growth rates for many of the countries, with a boom and bust in the 2000s. However, a direct comparison of house prices across countries should be done with some caution as the indices may be based on different types of properties (apartments, multi-family houses, etc.), in different locations (whole country, capital city, large cities only), including only existing dwellings or new dwellings, etc.

$<<$ Figure A.1 about here $>>$

While the main focus of this paper is to assess the spatial linkages across house prices, we control for country-specific factors which are associated with demand and supply drivers of house prices. The country-specific variables in our model are expressed in growth rates and include real gross domestic product (GDP) per capita, credit from domestic banks to the private non-financial sector as a share from GDP, consumer price index (CPI) inflation, total population, the share of

\footnotetext{
${ }^{7}$ We do not include Japan because only land values are available and there is no publicly available house price index.
} 
population between the ages of 20 and 44 years $^{8}$, unemployment rate, mortgage rate ${ }^{9}$, building permits ${ }^{10}$ and the exchange rate vis-a-vis the US dollar. As house prices adjust slowly to changes in economic indicators, we use the first lags of the explanatory variables instead of the contemporaneous relationship. Accordingly, the time-varying spatial weight matrix interacted with the country-specific variables is also lagged by one period. ${ }^{11}$ Definitions and sources of all variables in the models are provided in Table A.2. The macroeconomic variables are taken from the International Financial Statistics (IFS) of the International Monetary Fund (IMF), OECD, World Bank or Datastream. Since house price co-movements can be caused not only by bilateral linkages but also by global factors, we include oil prices and a measure of global financial leverage. The oil price is taken from Datastream. It is a good indicator of global economic cycles

\footnotetext{
${ }^{8}$ As a robustness check, we also use the household size and the share of urban population to proxy for demographic changes and the urbanization process. The data for number of people in a household comes from the Organisation for Economic Co-operation and Development (2011). The share of urban population comes from the World Bank. The results remain robust under these alternative specifications.

${ }^{9}$ There has been no time series of mortgage rates available for the full estimation period. From 2003 to 2012 we use the households borrowing costs for purchasing a new home from the European Central Bank (ECB) which are available for Austria, Belgium, Finland, France, Germany, Greece, Ireland, Italy, Netherlands and Spain. For the US we use the effective mortgage rate. In order to interpolate the above data back to 1990, we use the mortgage rate collected from national statistical offices of the above countries. For the remaining countries we also use the mortgage rate available from national sources. Where no mortgage rate data is available, we use the ten-year government bond yield in those countries that have fixed-rate mortgage rates as predominant mortgage contracts. For countries where a variable mortgage rate is more widely used, we choose the one-year government bond yield instead.

${ }^{10}$ Where no building permits are available housing starts have been used.

${ }^{11}$ The results regarding the co-movement coefficient are robust when either country-specific contemporaneous factors or lagged factors are included.
} 
and inflation expectations, whereas financial leverage is a good measure of financial risk appetite globally. During the financial crisis we have observed global deleveraging (Adrian and Shin, 2010; Shin, 2012), which affects the credit supply by reducing interbank flows and hence bank balance sheet size. We follow Bruno and Shin (2014) and measure global financial leverage as the sum of equity and total liabilities of US broker-dealers divided by their equity. The brokerdealer balance-sheet data comes from the US Flow of Funds. Broker-dealer leverage is closely, negatively associated with the VIX index of implied S\&P stock market volatility and can therefore also be associated with the risk appetite of investors internationally.

Table A.2 provides the sources and definitions for the weight matrices. Data for the trade matrix comes from the Trade Statistics of the OECD. The FDI bilateral flows are taken from the Foreign Direct Investment Statistics of the OECD. Data for the portfolio investment flows come from the CPIS database of the IMF. Regarding the bank flow weight matrix, we use bilateral bank claims based on the consolidated bank statistics of the BIS using Table $9 \cdot \mathrm{B}^{12}$. The consolidated statistics are based on the country of origin of the reporting bank and not on its location. It means that if, for example, a German bank has a subsidiary in the US, the foreign claims of the subsidiary are accounted as foreign claims by German banks and not US banks. These bank flow linkages are a good measure of financial integration. For example, the higher the claims of German banks on the US, the higher is their financial exposure to the US. Figure A.2 illustrates the average assetliability allocation of US, UK, and German banks from 1999 to 2012, towards the counterparty countries in the sample. The US banks have the largest foreign exposure followed by the UK and Switzerland, with the exposure being mainly on the liability side of their balance sheets. UK banks, in particular, have a high liability exposure to Germany and a high asset exposure to the

12 Data only dates back to 1999. Before 1999, we assume the bank claims keep constant at the level in 1999. 
US. The US has been acting as a net borrower from mainly UK, Switzerland, Germany, France and Canada. German banks are heavily acting as net lenders with the highest exposure to the US and the UK.

$<<$ Figure A.2 about here $>>$

\section{Results}

\subsection{Baseline results}

Table 1 shows the results for the baseline model (Model 2) using bilateral bank claims as a measure of bank integration and compares them to a conventional linear model (Model 1) which does not account for spatial linkages across housing returns. Comparing the likelihood ratio (LR in Table 1) of Model 2 against that of a conventional linear model shows that allowing for spatial correlation significantly increases the explanatory power of the model. The spatial coefficient $\rho$ is significant at $1 \%$ meaning that there is a significant co-movement across the housing markets. The higher the bank exposure, the stronger will be the co-movement with the counterparties. A $1 \%$ increase in housing returns in the foreign countries on average leads to an immediate $0.29 \%$ increase in domestic returns. While Asgharian et al. (2013) find larger spatial coefficients for equity returns of around $0.8 \%$, we show that the spatial co-movement is lower across the housing markets. This difference can be explained by the nature of real estate as an asset class. The housing market is highly illiquid and much more localized compared to the stock market, suggesting that correlations between housing markets in different countries should be lower, driven to a large extent by local factors.

With regards to the remaining variables of the model, the majority of the country-specific 
variables are significant and show the expected sign. The coefficient for credit-to-GDP growth is significantly positive, underlining the important role of credit provision for the build-up in house prices as housing is a highly credit-intensive asset. Economies with faster overall population growth also have significantly stronger house price growth. The demand for housing from buyers aged 20 to 44 can be stronger and more volatile compared to that from other age groups and can play an important role in shaping house prices. A major reason is that most first-time homebuyers - the predominant type of marginal home-buyers - are in this age group, which is both more active in entering the housing market and is more dependent on mortgage loans than other age cohorts. We therefore use the share of the population aged between 20 and 44 years to approximate for first-time home buyers and find that it has a significantly positive effect on housing returns. Countries that show higher GDP growth per capita also have significantly stronger house price growth. A high unemployment rate instead can lead to lower house price growth, which may be associated with a decrease in demand due to lower income and wealth expectations. Low mortgage rates also significantly contribute to increases in house prices as they are associated with a lower user cost of borrowing. In Model 3, we use the mortgage rate together with further controls to more precisely account for determinants of the user cost of housing. Poterba (1984) uses the concept of the user cost of housing to explain the decision of households of either owning or renting a house. The user cost of housing represents an 'opportunity cost' the forgone interest that the homeowner could have earned by investing in an alternative risk-free asset. It accounts for property taxes, tax deductibility of mortgage interest and property taxes, maintenance costs, expected capital gains or losses among others. We collect data on stamp duties which we use as a proxy for the property taxes. For tax deductibility and other measures that lower the burden of purchasing a house, we use a newly presented index of government participation, which is calculated by the IMF. We also account for the ease of access to the credit 
market and the increased leverage by looking at cross-country differences in the maximum LTV ratios. Additionally to the mortgage rate, we also include a dummy variable which captures the prevailing mortgage contract type, which can be a fixed rate, variable rate or a mix of both. The sources and definitions of the data used for the estimation of Model 3 are reported in Table A.2. However, we do not find that any of those additional controls have a significant effect on house price growth. The remaining variables in Model 3 show similar coefficients and the results remain robust under this specification. Therefore, we use Model 2 as our baseline model.

Since our baseline model accounts for the foreign country variables, it is interesting to compare how the same explanatory variables, averaged across countries using the bank flow matrix, affect domestic housing returns. In terms of significance, only foreign population, unemployment and inflation have significant effects. However, those coefficients have the opposite signs compared to the same variables capturing the domestic effects. This can be interpreted as a 'mobility effect'. On the one hand, there could be labour mobility: bad demographic and labour market conditions in one country can drive labour force to countries with better demographics and labour markets and this can lead to an increase in housing demand and house prices in those countries. On the other hand, there could be capital mobility associated with different levels of inflation across the countries. Countries with high inflation will attract more real-estate capital as real estate is considered a good inflation hedge. This may ease house prices in the domestic country which has lower inflation instead.

We should interpret the values of the coefficients in Models 1, 2 and 3 with some caution. They present only the average effect but do not capture any spillover or feedback effects. In order to account for the marginal effects that capture those spillovers, we calculate the marginal coefficients and present them in Model 2*. Now we can interpret the coefficients in the standard 
way. For example, a $1 \%$ increase in domestic population growth leads to a $1.9 \%$ increase in housing returns in the next quarter whereas a $1 \%$ increase in the average population growth abroad has the opposite effect, decreasing housing growth by $0.35 \%$.

Asgharian et al. (2013) find that the spatial coefficients are similar for the different measures of spatial proximity and that those coefficients have relatively large values. They argue that the reason for that could be that the cross-sectional correlation between stock market returns may be caused primarily by global co-movements of the returns. In order to tackle this issue we control for global co-movements of returns by including variables that capture global market variations such as financial leverage and oil prices. However, we do not observe any significant effects stemming from these variables. We run several robustness checks in the next section to ensure that our spatial measure is not associated with global linkages.

\section{Table 1: Baseline estimation: Bank integration and housing market linkages}

Note: Estimation for the period 1990Q1 to 2012Q4. Dependent variable is the quarterly log difference of house prices. The equation is estimated using maximum likelihood. $\rho$ is the contemporaneous spatial coefficient. The coefficient is based on the bank flow matrix. The country specific dummy variable coefficients are not reported for reasons of space. Model $2 *$ presents the marginal coefficients for the country-specific variables from Model 2. Model 1 does not account for spatial effects. Standard deviations are given in parentheses. ${ }^{* * *},{ }^{* *}$, and ${ }^{*}$ denote significance at the $1 \%, 5 \%$, and $10 \%$ level, respectively.

\begin{tabular}{lllll}
\hline & $\begin{array}{l}\text { Model 1: } \\
\text { Conventional } \\
\text { linear model }\end{array}$ & $\begin{array}{l}\text { Model 2: } \\
\text { Bank } \\
\text { integration } \\
\text { (average } \\
\text { effects) }\end{array}$ & $\begin{array}{l}\text { Model 2*: } \\
\text { Bank integration } \\
\text { (marginal effects) }\end{array}$ & $\begin{array}{l}\text { Model 3: } \\
\text { Bank } \\
\text { integration } \\
\text { (average } \\
\text { effects) }\end{array}$ \\
\hline$\rho$ & & $0.2658^{* * *}$ & & $0.2583^{* * *}$ \\
$(0.0371)$ & & $0.0373)$ \\
$\varphi$ & & $0.4769^{* * *}$ & & $0.4992^{* * *}$ \\
$\beta$ & $0.5510^{* * *}$ & $(0.0225)$ & & $(0.0223)$ \\
Credit-to-GDP & $(0.0221)$ & & & $0.0227^{* * *}$ \\
Housing permits & $0.0252^{* * *}$ & $0.0203^{* * *}$ & 0.0209 & $(0.0060)$ \\
Population & $(0.0060)$ & $(0.0060)$ & & 0.0014 \\
& 0.0025 & 0.0011 & 0.0013 & $(0.0027)$ \\
& $(0.0028)$ & $(0.0027)$ & & $1.2389^{* * *}$
\end{tabular}




\begin{tabular}{|c|c|c|c|c|}
\hline & $(0.5012)$ & $(0.4928)$ & & $(0.3984)$ \\
\hline Population 20-44 & $\begin{array}{l}0.6692^{* * *} \\
(0.2280)\end{array}$ & $\begin{array}{l}0.5497^{* *} \\
(0.2621)\end{array}$ & 0.5777 & $\begin{array}{l}0.2480 \\
(0.2150)\end{array}$ \\
\hline GDP per capita & $\begin{array}{l}0.1451^{* * *} \\
(0.0420)\end{array}$ & $\begin{array}{l}0.1240^{* * *} \\
(0.0425)\end{array}$ & 0.1254 & $\begin{array}{l}0.1151^{\text {*** }} \\
(0.0424)\end{array}$ \\
\hline Unemployment & $\begin{array}{l}-0.0041^{* * *} \\
(0.0013)\end{array}$ & $\begin{array}{l}-0.0050^{* * *} \\
(0.0014)\end{array}$ & -0.0049 & $\begin{array}{l}-0.0051^{* * *} \\
(0.0013)\end{array}$ \\
\hline Inflation & $\begin{array}{c}-0.1026 \\
(0.0799)\end{array}$ & $\begin{array}{l}0.1117 \\
(0.0887)\end{array}$ & 0.1007 & $\begin{array}{l}0.1999^{* * *} \\
(0.0786)\end{array}$ \\
\hline Exchange rate & $\begin{array}{l}0.0012 \\
(0.0032)\end{array}$ & $\begin{array}{l}0.0001 \\
(0.0034)\end{array}$ & 0.0003 & $\begin{array}{l}-0.0001 \\
(0.0035)\end{array}$ \\
\hline Mortgage rate & $\begin{array}{l}-0.0049^{* * *} \\
(0.0010)\end{array}$ & $\begin{array}{l}-0.0032^{* * *} \\
(0.0010)\end{array}$ & -0.0033 & $\begin{array}{l}-0.0036^{* * *} \\
(0.0010)\end{array}$ \\
\hline \multicolumn{5}{|l|}{$\lambda$} \\
\hline Credit-to-GDP & & $\begin{array}{l}0.0140 \\
(0.0170)\end{array}$ & 0.0016 & $\begin{array}{l}0.0131 \\
(0.0170)\end{array}$ \\
\hline Permits & & $\begin{array}{l}0.0062 \\
(0.0074)\end{array}$ & 0.0005 & $\begin{array}{l}0.0058 \\
(0.0075)\end{array}$ \\
\hline Population & & $\begin{array}{l}-4.7337^{* * *} \\
(1.4624)\end{array}$ & -0.3485 & $\begin{array}{l}-3.1917^{* * *} \\
(1.1499)\end{array}$ \\
\hline Population 20-44 & & $\begin{array}{l}0.7235 \\
(0.5337)\end{array}$ & 0.0723 & $\begin{array}{l}0.7211 \\
(0.4933)\end{array}$ \\
\hline GDP per capita & & $\begin{array}{l}0.0113 \\
(0.1198)\end{array}$ & 0.0037 & $\begin{array}{l}0.0289 \\
(0.1120)\end{array}$ \\
\hline Unemployment & & $\begin{array}{l}0.0066^{*} \\
(0.0034)\end{array}$ & 0.0004 & $\begin{array}{l}0.0067^{*} \\
(0.0035)\end{array}$ \\
\hline Inflation & & $\begin{array}{l}-0.3705^{* * *} \\
(0.1861)\end{array}$ & -0.0283 & $\begin{array}{l}-0.4348^{* * *} \\
(0.1822)\end{array}$ \\
\hline Exchange rate & & $\begin{array}{l}0.0049 \\
(0.0070)\end{array}$ & 0.0004 & $\begin{array}{l}0.0052 \\
(0.0070)\end{array}$ \\
\hline Mortgage rate & & $\begin{array}{l}-0.0012 \\
(0.0019)\end{array}$ & -0.0002 & $\begin{array}{l}-0.0012 \\
(0.0019)\end{array}$ \\
\hline \multicolumn{5}{|l|}{$\gamma$} \\
\hline Oil price & $\begin{array}{l}0.0010 \\
(0.0027)\end{array}$ & $\begin{array}{l}0.0021 \\
(0.0032)\end{array}$ & & $\begin{array}{l}0.0017 \\
(0.0032)\end{array}$ \\
\hline Financial leverage & $\begin{array}{l}-0.0004 \\
(0.0004)\end{array}$ & $\begin{array}{l}-0.0002 \\
(0.0004)\end{array}$ & & $\begin{array}{c}-0.0002 \\
(0.0004)\end{array}$ \\
\hline Country-specific dummy & Yes & Yes & & No \\
\hline Variable mortgage rate & & & & $\begin{array}{c}-0.0016 \\
(0.0011)\end{array}$ \\
\hline Maximum LTV ratio & & & & $\begin{array}{l}0.0030 \\
(0.0035)\end{array}$ \\
\hline Government participation & & & & $\begin{array}{c}-0.0053 \\
(0.0045)\end{array}$ \\
\hline
\end{tabular}




\begin{tabular}{llll} 
Stamp duty & \multicolumn{2}{c}{-0.0057} \\
\hline LL & 4255.9 & 4308.2 & 4295.7 \\
MSE & 0.00024 & 0.00022 & 0.00022 \\
Adjusted R2 & 0.4413 & 0.4785 & 0.4740 \\
LR & $104.6^{* * *}$ & & \\
\hline
\end{tabular}

\subsection{Controlling for unobservable and global drivers}

First, we compare the performance of our bank flow matrix against a model using a randomly generated weight matrix instead (see Equation (15)). We run the simulation 200 times, adding a randomly generated matrix into the regression. The results are presented under Model 4 in Table 2. The $95 \%$ inner-percentile range of the distribution of the estimates is shown. We can see that the confidence intervals for the spatial coefficient do not overlap with those for the randomly generated weight matrices. Thus, the variations in the returns can indeed be driven by banking integration and not by strong global co-movements of the returns. This result also shows that the measure of banking integration outperforms the majority of randomly generated weight matrices best capturing the spatial co-movement among the selected countries.

Second, following Asgharian et al. (2013), we perform an additional robustness test controlling for global drivers by splitting the foreign countries into two groups - neighbors and nonneighbors (see Equation (14)). From the perspective of a single country, out of the 16 remaining countries, the neighbors are the 8 countries that have the strongest bank exposure to it. Nonneighbors are the remaining 8 countries - these are the countries that have the weakest bank exposure to the country of interest. For example, if we split the countries according to their average bank exposure to the US from 1999 to 2012, the US's neighbors would be Belgium, Canada, Germany, France, the Netherlands, Sweden, Switzerland and the UK. The non-neighbors include the remaining 8 countries. Once the neighbors and non-neighbors are identified, we 
construct two weight matrices for bank integration. The first matrix is referred to as the neighboring matrix $(n b)$. It includes only the countries with the highest bilateral bank exposure and the weight for the remaining 8 countries is set to zero. The second is the non-neighboring matrix (non-nb) which consists of only the countries with the weakest bilateral bank exposure and the weight for the remaining countries is zero. The results are presented in Model 5 in Table 2. We observe similar results as above where we used the randomly generated weight matrices. The spatial coefficients of the neighboring and non-neighboring matrices are different and the confidence bands do not overlap. The coefficient of the neighboring matrix is significantly positive while the coefficient of the non-neighboring matrix is insignificant, indicating that the co-movement effect is not driven by global common factors. Overall, a proximity measure based on bank foreign claims is suitable to identify co-movements, based on the degree of bank integration among countries performing better than a random matrix and yielding different estimates for neighbors and non-neighbors.

\section{Table 2: Robustness analysis controlling for global factors}

Note: Dependent variable is the quarterly log difference of house prices. $\rho$ is the contemporaneous spatial coefficient. For more details see the Note in Table 1. The upper and lower 95\% confidence intervals are reported in parentheses.

\begin{tabular}{lll}
\hline & $\begin{array}{l}\text { Model 4: Bank } \\
\text { integration and } \\
\text { a random weight } \\
\text { matrix }\end{array}$ & $\begin{array}{l}\text { Model 5: Bank } \\
\text { integration for } \\
\text { neighbors and non- } \\
\text { neighbors }\end{array}$ \\
\hline Bank integration $\rho$ & $0.2646^{* * *}$ & \\
& {$[0.1916,0.3341]$} & \\
Random weight matrix $\rho$ & -0.0145 & \\
Bank integration of & {$[-0.1177,0.0976]$} & \\
neighbors $\rho$ & & $0.2326^{* * *}$ \\
Bank integration of non- & & {$[0.1361,0.3291]$} \\
neighbors $\rho$ & & 0.0413 \\
\hline
\end{tabular}




\subsection{Alternative estimators}

The above models are estimated using a maximum likelihood (ML) estimation, which is the standard way to deal with the inefficiency of the coefficients resulting from the inclusion of a spatial term. Other estimators proposed in the literature are a Bayesian estimator with heteroscedastic errors and an instrumental variable (IV) estimator. In order to see whether the choice of the estimation will affect the baseline results, we solve Equation (1) using those alternative estimations. The results are reported in Table 3. Model 6 shows the results based on the Bayesian estimation. The spatial coefficient is quite similar to that based on the ML, suggesting that the ML estimator is not strongly affected by the homoscedasticity assumption. ${ }^{13}$ With regards to the IV estimation, we have used several instruments as Kelejian and Prucha (1998), Beenstock and Felsenstein (2007) and others suggest. The results vary slightly across the estimates with the coefficients ranging from 0.30 to 0.36 . We report the results in Model 7 with the estimate which is closest to the baseline estimate. Overall, the results do not change much across the different estimations.

\section{Table 3: Robustness analysis using alternative estimators}

Note: Dependent variable is the quarterly log difference of house prices. $\rho$ is the contemporaneous spatial coefficient. The remaining coefficients are not reported for reasons of space but remain robust. For further reference see the Note in Table 1. Model 6 shows the 95\% Bayesian confidence bands in parentheses. The standard deviation is given in parentheses for Model 7. ${ }^{* * *},{ }^{* *}$, and ${ }^{*}$ denote significance at the $1 \%, 5 \%$, and $10 \%$ level, respectively.

\begin{tabular}{lll}
\hline & $\begin{array}{l}\text { Model 6: } \\
\text { Bayesian } \\
\text { Estimator }\end{array}$ & $\begin{array}{l}\text { Model 7: } \\
\text { IV } \\
\text { Estimator }\end{array}$ \\
\hline$\rho$ & $0.2619^{* * *}$ & $0.3036^{* * *}$ \\
& {$[0.2001 ; 0.3256]$} & $(0.0494)$ \\
\hline LL & 4283.1 & \\
Adjusted R2 & & 0.4713 \\
\hline
\end{tabular}

\footnotetext{
${ }^{13}$ When additional weight matrices are added, the conclusion that the bank flow matrix can add additional information to other measures of proximity remains the same.
} 


\subsection{Alternative measures of bank exposure}

In order to assess whether there are differences between asset-side and liability-side bank exposures, we split total bank flows calculated as the sum of claims between each of the countries into assets and liabilities, and construct the weights as described in section 3.3. The reason is that total bank exposure can be associated with either asset risks or liability risks. ${ }^{14}$ Models 8 and 9 in Table 4 present the results for the spatial coefficients for bank liability and asset exposure respectively. We can see that both types of exposure significantly contribute to explaining the comovement across housing markets. Bank liability exposure has a stronger impact on return comovements. However, the asset exposure can also capture well the linkages across the housing markets as the log likelihood value of the asset model is very close and even higher than that of the liability model (4300.3). The liability and the asset bank exposures provide the upper and lower bound, respectively, for the coefficient of total balance-sheet exposure.

Another concern resulting from the use of time-varying cross-border exposures is that we cannot directly account for movements in credit standards across countries, across time. This means that some of the estimated impact of cross-border flows may pick up movements in omitted variables. This is particularly relevant for the US as shown in Duca et al. (2011). The importance of changes in credit standards has also been assessed in studies for the UK (Muellbauer and Murphy, 1997).

\footnotetext{
${ }^{14}$ On the asset side, if banks increase foreign flows they face higher credit risks also reflecting an increase in leverage. On the liability side, there are funding risks since banks rely heavily on funding from abroad. Moreover, there is a maturity mismatch risk since banks borrow from the wholesale market and thus most liabilities are shortterm positions while most assets are long-term loans. Further risks may stem from exchange rate fluctuations, especially that vis-à-vis the US dollar, since most global banks would borrow on the US wholesale market.
} 
Ireland is also a country that experiences notable swings in its credit standards and house prices (McCarthy and McQuinn, 2013). While Duca et al. (2011) use cyclically adjusted loan-to-value ratios to account for credit standards, there isn't time-varying data that measures shifts in credit standards for all the countries in the sample. As a result, the role of cross-border exposures to countries in which credit standards have been weakened in housing booms may be upwardly biased. Other events which may have the opposite effect and limit the role of cross-border exposures are the bailout policies undertaken by governments in countries with distressed banking sectors (e.g. Spain, Ireland, US, Switzerland) as well as the central banks' policies of purchasing subprime bond holdings. This can limit the damage of housing losses in one country on banks in the other countries, and on the housing markets in those countries. One way we can test the robustness of our results with regards to this concern is to use a time-varying weight matrix. Therefore, we substitute the time-varying weight matrix from Model 2 by a timeunvarying matrix that uses the bank flow in 1999. The results are presented in Model 10. The coefficient is 0.2438 , which is very similar to the value of the coefficient in the baseline estimation of 0.2658 .

\section{Table 4: Robustness analysis using alternative measures of bank exposure}

Note: Dependent variable is the quarterly log difference of house prices. $\rho$ is the contemporaneous spatial coefficient. The remaining coefficients are not reported for reasons of space but remain robust. For further reference see the Note in Table 1. Standard deviations are given in parentheses. ${ }^{* * *},{ }^{* *}$, and ${ }^{*}$ denote significance at the $1 \%$, 5\%, and $10 \%$ level, respectively.

\begin{tabular}{llll}
\hline & $\begin{array}{l}\text { Model 8: } \\
\text { Bank asset } \\
\text { exposure }\end{array}$ & $\begin{array}{l}\text { Model 9: } \\
\text { Bank liability } \\
\text { exposure }\end{array}$ & $\begin{array}{l}\text { Model 10: } \\
\text { Time- } \\
\text { unvarying } \\
\text { matrix }\end{array}$ \\
\hline$\rho$ & $0.2283^{* * *}$ & $0.2908^{* * *}$ & $0.2438^{* * *}$ \\
$(0.0341)$ & $(0.0440)$ & $(0.0391)$ \\
\hline LL & 4307.2 & 4300.3 & 4303.3 \\
Adjusted R2 & 0.4762 & 0.4731 & 0.4742 \\
\hline
\end{tabular}




\subsection{Accounting for additional spatial linkages}

One of the main contributions of this paper is that it does not assess the role of bank integration for spatial co-movement across housing markets alone but it compares it against other measures of proximity. We test whether bank flow linkages can add further information to other spatial linkages traditionally used to account for spatial return co-movements by adding an additional weight matrix next to the bank flow matrix each time. We combine our measure of bank integration with measures of trade integration, investment integration, openness proximity, geographic proximity, interest rate convergence and inflation convergence. If the inclusion of another spatial matrix does not affect the significance of the coefficient capturing bank integration, then we can argue that our proposed measure of spatial dependence can add to the model. Moreover, if the 'non-bank' spatial coefficient is insignificant we can show that there may be other reasons for the spatial co-movements across returns different from what has been considered so far in spatial econometric models. Table 5 presents the results for seven different combinations of two spatial matrices - for brevity we call them a bank and a non-bank matrix. We see that the spatial coefficient capturing the return co-movements using bank integration remains significant throughout all specifications. All other spatial linkages seem not to capture housing co-movements significantly. The coefficient in front of the bank matrix is slightly lower than under the baseline estimation and shows some variation ranging from 0.1745 , when a trade matrix is included, to 0.2867 , when interest rate convergence is accounted for.

More traditional measures of spatial co-movement, such as trade linkages, portfolio investment linkages, FDI linkages or openness, are insignificant (see Models 11-14 in Table 5). These results differ from most previous research, which usually uses only one weight matrix as a sole measure of proximity. Indeed, Fernandez-Aviles et al. (2012) suggest that the FDI linkages may actually 
capture patterns stemming from the bank balance-sheet exposure. Asgharian et al. (2013) compare different measures of spatial proximity one by one and find that trade best captures the co-movement in stock returns across countries. Although trade has the highest coefficient among all other non-bank matrices (see Model 12), its spatial coefficient is insignificant. We also replace trade (investment) by a more general measure of economic openness (see section 3.3). We can see that openness remains insignificant with an even lower coefficient (Model 14). This does not mean that there are no important trade or investment linkages. However, bank integration can better capture the housing market co-movements as the transmission through the credit market is more direct than through trade. Therefore, even if countries are bound by strong trade and investment linkages, the foreign banking penetration can be a more important driver of housing market co-movements.

Models 15 and 16 show the results, including a matrix capturing interest rate convergence and a matrix capturing inflation convergence, respectively. Previous studies (Marston, 1997; Asgharian et al., 2013) use interest-rate proximity as a proxy for financial integration, under the premise that countries with similar interest rates may have better capital mobility and less arbitrage opportunities. This measure may capture the broader financial integration to some extent, but it does not account for the globalization of the banking markets. Bank balance-sheet exposure can be a better proxy since financial frictions are more likely to be transmitted through balance sheets of banks, as demonstrated during the global financial crisis.

Model 17 includes bank flow and geographic distances. Zhu et al. (2013) show, for US regional house prices, that next to geographic closeness, economic proximity is also an important driver in spatial linkages across property returns. Our results are consistent with studies that go beyond 
geographic distance as a sole spatial measure. We can see that geographic proximity is insignificant. It can be that the linkages previously captured only by geographic distance are weakened once another measure of proximity, associated with stronger co-movement of returns is included.

\section{Table 5: Model estimations with bank integration and an additional spatial matrix}

Note: Dependent variable is the quarterly log difference of house prices. The estimation includes two weight matrices (see Section 3.3 for matrix descriptions). $\rho$ is the contemporaneous spatial coefficient. The remaining coefficients are not reported for reasons of space. However, they remain robust comparable to the results in Table 1. LR (bank) tests whether adding an additional matrix to the bank flow weight matrix can substantially improve the model's fit compared with the model only based on the bank flow weight matrix (Model 2 in Table 1). The null hypothesis states that there is no difference in the goodness of fit between the two models. LR (non-bank) compares the goodness of fit between the model with two matrices (bank and non-bank weight matrix) against a model including only the non-bank matrix. Standard deviations are given in parentheses. ${ }^{* * *},{ }^{* *}$, and ${ }^{*}$ denote significance at the $1 \%, 5 \%$, and $10 \%$ level, respectively.

\begin{tabular}{|c|c|c|c|c|c|c|c|}
\hline & $\begin{array}{l}\text { Model } \\
\text { 11: Bank } \\
\text { flows and } \\
\text { FDI }\end{array}$ & $\begin{array}{l}\text { Model } \\
\text { 12: Bank } \\
\text { flows and } \\
\text { trade }\end{array}$ & $\begin{array}{l}\text { Model } \\
\text { 13: Bank } \\
\text { flows and } \\
\text { portfolio } \\
\text { investment }\end{array}$ & $\begin{array}{l}\text { Model } \\
\text { 14: Bank } \\
\text { flows and } \\
\text { openness }\end{array}$ & $\begin{array}{l}\text { Model } \\
\text { 15: Bank } \\
\text { flows and } \\
\text { interest rate }\end{array}$ & $\begin{array}{l}\text { Model } \\
\text { 16: Bank } \\
\text { flows and } \\
\text { inflation }\end{array}$ & $\begin{array}{l}\text { Model } \\
\text { 17: Bank } \\
\text { flows and } \\
\text { geographic } \\
\text { distance }\end{array}$ \\
\hline $\begin{array}{l}\text { Bank } \\
\text { integration } \rho\end{array}$ & $\begin{array}{l}0.2210^{* * *} \\
(0.0706)\end{array}$ & $\begin{array}{l}0.1745^{* *} \\
(0.0779)\end{array}$ & $\begin{array}{l}0.2377^{* * *} \\
(0.0884)\end{array}$ & $\begin{array}{l}0.2604^{* * *} \\
(0.0592)\end{array}$ & $\begin{array}{l}0.2867^{* * *} \\
(0.0630)\end{array}$ & $\begin{array}{l}0.2520^{* * *} \\
(0.0616)\end{array}$ & $\begin{array}{l}0.2475^{* * *} \\
(0.0548)\end{array}$ \\
\hline $\begin{array}{l}\text { FDI } \\
\text { integration } \rho\end{array}$ & $\begin{array}{l}0.0504 \\
(0.0659)\end{array}$ & & & & & & \\
\hline $\begin{array}{l}\text { Trade } \\
\text { integration } \rho\end{array}$ & & $\begin{array}{l}0.1088 \\
(0.0784)\end{array}$ & & & & & \\
\hline $\begin{array}{l}\text { Portfolio } \\
\text { investment } \\
\text { integtation } \rho\end{array}$ & & & $\begin{array}{l}0.0122 \\
(0.0929)\end{array}$ & & & & \\
\hline $\begin{array}{l}\text { Openness } \\
\text { proximity } \rho\end{array}$ & & & & $\begin{array}{l}-0.0232 \\
(0.0681)\end{array}$ & & & \\
\hline $\begin{array}{l}\text { Interest rate } \\
\text { convergence } \rho\end{array}$ & & & & & $\begin{array}{l}-0.0507 \\
(0.0748)\end{array}$ & & \\
\hline $\begin{array}{l}\text { Inflation } \\
\text { convergence } \rho\end{array}$ & & & & & & $\begin{array}{l}0.0018 \\
(0.0765)\end{array}$ & \\
\hline $\begin{array}{l}\text { Geographic } \\
\text { proximity } \rho\end{array}$ & & & & & & & $\begin{array}{l}-0.0052 \\
(0.0556)\end{array}$ \\
\hline LL & 4309.2 & 4315.9 & 4317.6 & 4315.9 & 4322.7 & 4317.7 & 4316.6 \\
\hline
\end{tabular}




\begin{tabular}{llllllll} 
Adjusted R2 & 0.4758 & 0.4808 & 0.4808 & 0.4796 & 0.4844 & 0.4810 & 0.4801 \\
LR (bank) & 2.0 & 15.4 & $18.8^{*}$ & 15.4 & $29.0^{* * *}$ & $19.0^{* *}$ & $16.8^{* *}$ \\
LR (non-bank) & $19.2^{* *}$ & $18.8^{* *}$ & $27.0^{* * *}$ & $43.8^{* * *}$ & $57.8^{* * *}$ & $48.6^{* * *}$ & $52.4^{* * *}$ \\
\hline
\end{tabular}

The likelihood ratio LR (bank) in Table 5 tests whether adding an additional matrix to the bank exposure weight matrix can substantially improve the model's fit, compared to a model based only on the bank exposure weight matrix (Model 2 in Table 1). The null hypothesis is that there is no difference in the goodness of fit between the two models. We can see that with the exception of the models, including FDI, trade and openness, the null hypothesis is rejected for all the other models. Although portfolio investment, interest rate, inflation convergence or geographic distance cannot add additional information to the spillover effect between housing markets, they still play important roles in explaining the 'mobility effect' between countries through their interaction with the country-specific variables. This means they can better capture the impact of foreign population growth and unemployment rate on the domestic countries. On the other hand, LR (non-bank) compares the goodness of fit between each model with two matrices (a bank and non-bank weight matrix) against a model including only the non-bank matrix. The likelihood ratio is significant for all models, suggesting that bank exposure significantly adds information to the other measures of distance.

\subsection{Bank integration and mortgage market development}

As shown in Figure A.2, the main players in the bank flow spatial matrix are the US, UK and Germany due to the importance of their banks as net borrowers or net lenders. For example, it is interesting that although Germany shows strong bank integration with the US and UK, house prices in Germany have not followed the same pattern as in those two countries. Prices in Germany have been quite stable during the boom-bust period of the last decade, observed in 
many developed countries. A part of it may be due to differences in the mortgage market development across the different countries. Germany, for example, does not provide the option of MEW available in the US which will enable households to withdraw equity out of the increased value of their houses and use it for investment or consumption purposes, thus further driving up housing demand. Moreover, mortgage contracts are typically based on 10-year fixed mortgage rate contracts providing more predictability for households and, eventually, smoother intertemporal consumption. LTV ratios for Germany are also among the lowest in our country sample (see Table A.4).

Previous studies show that heterogeneous mortgage markets can explain why housing markets respond differently to exogenous shocks (Iacoviello, 2005; Musso et al., 2011; Calza et al., 2013). Carstensen et al. (2009) show that in countries with more flexible mortgage markets monetary policy shocks have more pronounced effects on the housing market. Given the above differences in mortgage market development across countries, we want to further investigate the relationship between institutional characteristics of mortgage markets and spatial co-movements. We, therefore, want to assess whether a less flexible mortgage market can offset the housing shocks from foreign countries. In order to test this assumption we include mortgage market variables and interact them with the spatial linkages captured by bank integration to assess whether the spatial coefficient changes significantly, according to the degree of mortgage market development. We estimate the model:

$Y_{t}=\left(\rho^{*} I+\operatorname{Mort} \rho^{* *}\right) W_{t} Y_{t}+\varphi Y_{t-1}+X_{t} \beta+W_{t} X_{t} \lambda+Z_{t} \gamma+D \alpha+e_{t}$

where $I$ stands for an $N \times N$ identity matrix. Mort denotes a $N \times N$ diagonal matrix with 
diagonal items consisting of the values presented in Table A4. Those values are standardized to account for the mortgage market development of country $i$ relative to all other countries. We estimate several specifications, presented in Table 6, accounting for different factors of mortgage market development - such as the type of mortgage market rate, MEW, maximum LTV ratios, securitisation size and government participation. These measures are collected from different sources which are reported in Table A.4. We also calculate an equally weighted average of all five determinants which we interpret as a measure of overall mortgage market development. Similar approaches to assess the mortgage market flexibility have been adopted in previous studies, such as Tsatsaronis and Zhu (2004), IMF (2008) and ECB (2009). Some variables take values of either 1 or 0 (mortgage market rate, MEW), while others are represented in percentages - values between 0 and 1 (maximum LTV ratio, securitisation, government participation, overall mortgage market development). The higher the value in Mort, the less developed the mortgage market is. For instance, a country with 1 for mortgage rate in the matrix Mort has a fixed mortgage rate. Similarly, a country with a high LTV 'score' - the normalized reversed value of the actual LTV ratio - in Mort actually has low LTV ratio.

The coefficient $\rho^{* *}$ is the spatial coefficient for the interaction term, which is expected to show the opposite sign to the sign of the spatial coefficient $\rho^{*}$. The interaction coefficient $\rho^{* *}$ should hence partially offset the spatial coefficient $\rho^{*}$, because the elements of the mortgage matrix Mort take high values for the countries with low mortgage market development - those countries with less flexible mortgage markets will tend to have weaker overall housing market co-movement, ceteris paribus. The results are presented in Table 6 . We can see that all interaction coefficients have a negative sign, which means that countries with less developed mortgage markets show less co-movement of housing returns. The coefficients are significant for the type of mortgage 
rate, MEW and LTV ratios, meaning that the presence of fixed rate mortgages, the lack of MEW and low maximum LTV ratios in particular, can weaken the spatial linkages captured by bank integration.

The overall degree of mortgage market development is important and can affect the return comovements, as shown by the significance of the coefficient in Model 23 in Table 6. Indeed, the coefficient for the mortgage market development matrix can completely offset the spatial effects - as we see, the interaction coefficient is even larger in absolute terms than the spatial coefficient. The largest coefficient of the elements included in the mortgage market development is observed for the maximum LTV ratio (see Model 20). LTV ratios can affect the degree of spatial transmission through the credit channel. Since LTV ratios measure the degree of household leverage, the channel can work as follows: in countries with high LTV ratios, borrowers are more leveraged and respond more strongly to changes in house prices, and as a result they can more strongly increase or decrease their housing demand compared to less leveraged households. Our findings have important policy implications for macro-prudential policy and the design of the mortgage markets. Policy makers can offset the effects of housing spillovers reaching the domestic market by adopting a more conservative policy, using as instruments the type of mortgage rate, the level of the maximum LTV ratios and the availability of MEW. As Mendicino and Punzi (2014) show in a DSGE model, LTV ratios can be used as a monetary policy instrument when conducting macro-prudential policy in order to mitigate the procyclicality arising from the interlinkages on the mortgage markets. Rubio and Carrasco-Gallego (2014) also use a DSGE model to show that LTV ratios can be used as a macro-prudential tool to improve financial stability.

\section{Table 6: Bank integration interacted with mortgage market variables}

Note: Dependent variable is the quarterly log difference of house price. $\rho^{*}$ is the contemporaneous spatial coefficient and $\rho^{* *}$ is the spatial coefficient for the interaction term (here the mortgage matrix). All the other coefficients remain 
robust but are not presented for reasons of space. The LR indicates whether adding the interaction term to the bank flow matrix can substantially improve the model's fit compared to the model based only on bank integration (Model 2 in Table 1). The null hypothesis is there is no difference in the goodness of fit between the two models. Standard deviations are given in parentheses. ${ }^{* * *},{ }^{* *}$, and ${ }^{*}$ denote significance at the $1 \%, 5 \%$, and $10 \%$ level, respectively.

\begin{tabular}{|c|c|c|c|c|c|c|}
\hline & $\begin{array}{l}\text { Model } \\
18: \\
\text { Bank } \\
\text { integration } \\
\text { interacted with } \\
\text { variable } \\
\text { mortgage rate }\end{array}$ & $\begin{array}{l}\text { Model } \\
\text { 19: } \\
\text { Bank } \\
\text { integration } \\
\text { interacted with } \\
\text { MEW }\end{array}$ & $\begin{array}{l}\text { Model } \\
\text { 20: } \\
\text { Bank } \\
\text { integration } \\
\text { interacted with } \\
\text { Max LTV }\end{array}$ & $\begin{array}{l}\text { Model } \\
21: \\
\text { Bank } \\
\text { integration } \\
\text { interacted with } \\
\text { securitisation }\end{array}$ & $\begin{array}{l}\text { Model } \\
\text { 22: } \\
\text { Bank } \\
\text { integration } \\
\text { interacted with } \\
\text { Government } \\
\text { Participation }\end{array}$ & $\begin{array}{l}\text { Model } \\
\text { 23: } \\
\text { Bank } \\
\text { integration } \\
\text { interacted } \\
\text { with mortgage } \\
\text { market } \\
\text { development }\end{array}$ \\
\hline $\begin{array}{l}\text { Bank integration } \\
\rho^{*}\end{array}$ & $\begin{array}{l}0.3787^{* *} \\
(0.0559)\end{array}$ & $\begin{array}{l}0.3887^{* * *} \\
(0.0479)\end{array}$ & $\begin{array}{l}0.4890^{* * *} \\
(0.0957)\end{array}$ & $\begin{array}{l}0.3253^{* * *} \\
(0.0969)\end{array}$ & $\begin{array}{l}0.2689^{* * *} \\
(0.0944)\end{array}$ & $\begin{array}{l}0.4530^{* * *} \\
(0.0561)\end{array}$ \\
\hline $\begin{array}{l}\text { Bank integration } \\
\text { interacted with } \\
\text { mortgage market } \\
\text { development } \rho^{* *}\end{array}$ & $\begin{array}{l}-0.2314^{* * *} \\
(0.0837)\end{array}$ & $\begin{array}{l}-0.2815^{* * *} \\
(0.0694)\end{array}$ & $\begin{array}{l}-0.3095^{* * *} \\
(0.1221)\end{array}$ & $\begin{array}{l}-0.0901 \\
(0.1347)\end{array}$ & $\begin{array}{l}-0.0066 \\
(0.1548)\end{array}$ & $\begin{array}{l}-0.4604^{* * *} \\
(0.1041)\end{array}$ \\
\hline LL & 4312.3 & 4316.5 & 4311.8 & 4308.6 & 4308.2 & 4318.2 \\
\hline Adjusted R2 & 0.4803 & 0.4840 & 0.4811 & 0.4786 & 0.4782 & 0.4848 \\
\hline LR & $8.2^{* * *}$ & $16.6^{* * *}$ & $7.2^{* * *}$ & 0.2 & 0 & $20.0^{* * *}$ \\
\hline
\end{tabular}

\subsection{Impulse response analysis}

The advantage of a spatial model is that it allows us to investigate how a change in the dependent variable in one country transmits throughout the spatial system to the other countries. Due to the dynamic nature of the spatial framework, applied return variations in one country would affect the returns in countries with high bank exposure to the source country. The resulting movements in those markets will, in turn, affect their 'neighboring' markets, and so on. For the transmission of the spatial shocks, we calculate the impulse responses following a one unit country-specific foreign shock. The estimations are based on Equation (26) using the different mortgage matrices.

Figure A.3 shows the average spatial effect of a unit shock in one country on house price growth globally. The effect is highest in the second quarter and is not short-lived as it lasts for more than two years. The effect remains quite strong in the first year and reduces by a half after five 
quarters. The countries with the strongest impact on housing markets internationally are the US, UK and Germany. A unit shock to any of these countries will increase housing returns in the remaining countries on average by about 0.07 . France is also an important driver of comovements, with an average impact of 0.04 . These results are determined by our spatial matrix the bank flows - hence, they are not surprising since the countries above are important net borrowers or lenders to most other countries.

$<$ Figure A.3 about here $>$

Figure A.4 shows the impact of a unit shock to house price growth in the US, UK or Germany on housing markets in the remaining countries individually. The strongest response to the US housing shock is shown by Canada, with housing returns increasing by about 0.17 . This can be explained by the high exposure of Canadian banks towards the US. Also, we see strong exposure of Swiss and UK banks and, hence, strong spillover effects of between 0.14 and 0.09 . With the above exceptions, we find that the remaining countries show an akin level of response, which underlines the importance of the US housing market and the US as a net borrower for the comovement of housing markets internationally. The UK has the strongest impact on Australia and Ireland, increasing their housing returns by ca. 0.12 and ca. 0.1 respectively. The UK also affects Germany, Spain, Switzerland and US. The strongest effect of a German shock is observed for Austria (0.12), followed by the remaining pan-European countries. The weakest effect is observed for Canada. Interestingly, estimates for the above countries show that physical distance is not always associated with a strong response to a foreign shock - which may be explained by the nature of our spatial linkages - with linkages also existing even between distant countries, such as UK and Australia. 
$<$ Figure A.4 about here $>$

Figure A.5 compares the responses of the countries in different models - the baseline model (Model 2) and the models that include the mortgage market variables (Models 18-23). The black bars present the average response of individual countries to a foreign shock in the baseline model. A foreign shock to one country is defined as the average magnitude of shocks coming from all other countries simultaneously. Since our main research focus is the spatial transmission of regional shocks, we only show the part of the response that stems from the housing shock in the other countries. In addition, it should also be noted that Figure A.5 only shows the response in the subsequent second quarter after the shock, since all these average responses reach their highest levels in the second quarter. We observe that following the foreign shock, all countries in the sample are similarly affected with a maximum response of 0.025 . The similar responses are explained by the construction of the spatial linkages in Equation (1). A foreign shock in housing returns will have a similar effect on each country because the spatial coefficient $\rho$ is the same for all countries, and the individual country effects average out through the spatial matrix. However, if we account for the mortgage market development, we observe more variation in the response to the foreign shock. This can be seen from the construction of the model in Equation (26) where, through the introduction of the mortgage matrix, we obtain a country-varying spatial coefficient $\rho^{* *}$ Mort. This creates additional variation across the countries, which is determined by their mortgage market development. We observe that some countries increase their response while others decrease it following the foreign shock. When looking at total mortgage market development, responses across countries vary greatly. While Australia, Canada, Finland, Ireland, Sweden, the UK and the US react more strongly to the foreign shock, Austria, Belgium, France 
and Germany show almost no response anymore to the foreign housing shock. If, instead, we assess each mortgage market indicator separately, we observe similar patterns across the countries.

The effect from the foreign shock in the model with maximum LTV ratios increases most in the Netherlands (0.047). Above average responses are estimated for Australia, Belgium, Finland, France, Ireland, Spain, the UK and the US, while below average responses are found for Austria, Canada, Denmark, Germany, Greece, Italy, Sweden and Switzerland. However, the fluctuations across the countries are less pronounced as for the other mortgage variables. More variations are observed when accounting for the type of mortgage rate contract. Australia, Finland, Greece, Ireland, Spain, Sweden and the UK respond more strongly to the shock due to their variable mortgage rate contracts. Austria, Belgium, France, Germany, the Netherlands and the US, meanwhile, show much weaker responses to the foreign shock as compared to the baseline model. A similar pattern is observed for the MEW. It is mainly the Nordic and Anglo-Saxon countries that show the stronger responses; the remaining countries show a much weaker response to the shock. Overall, mortgage market indicators can enhance or weaken the spatial transmission to the housing markets through bank integration.

$<<$ Figure A.5 about here $>>$

Figure A.6 shows how US, UK or Germany respond to country-specific shocks in a model with and without the variable controlling for mortgage market development. The change in the impact of a country-specific shock is similar for the US and the UK, while a slightly different picture is observed for Germany instead. The US and UK respond more strongly to shocks from all 
countries $^{15}$, but those differences are larger for shocks from France, Germany, Switzerland and the UK or US respectively, once we account for mortgage market development. In turn, Germany shows no response to shocks in any of the countries, including the UK and the US. This result is not surprising given the observation that the German mortgage market shows a low level of flexibility. The transmission through LTV ratios or MEW is not possible so the credit channel weakens since. In turn, foreign shocks in the UK and the US can be amplified because their mortgage markets are more flexible.

$<<$ Figure A.6 about here $>>$

\section{Conclusion}

We have assessed how bank integration, as measured by the bilateral bank exposure, can capture the co-movements across housing markets in developed countries using a dynamic spatial panel model. Housing variations can have spillover effects on other countries through the global banking channel. Global banks intermediate wholesale bank funding to domestic banks, thus affecting domestic credit supply and asset prices by transmitting financial conditions across borders. Countries with stronger bilateral bank flows are more strongly exposed to asset-side and liability-side risks such as currency, maturity mismatch, credit and funding risks. While controlling for country-level and global factors, we find that bank integration can significantly capture the co-movement of housing returns. Housing markets with stronger bank balance-sheet exposure show stronger housing return linkages. We have shown that bank integration can not

15 The effects for the US and UK are consistent with Aron et al. (2012) who assess differences in housing wealth effects across Japan, the UK, and the US. 
only add additional information next to other spatial linkages - such as trade, FDI, geographic proximity, etc. - but is the only spatial matrix that can significantly capture the return comovements. Moreover, we find that the co-movement across housing markets can be partially or entirely offset if the countries have less flexible mortgage markets characterized by fixed mortgage rates, low LTV ratios and lack of MEW. These findings have important policy implications for macro-prudential policy and the design of mortgage markets. LTV ratios can be used as a tool when conducting macro-prudential policy in order to mitigate the procyclicality arising from the interlinkages on the mortgage markets. Policy makers can offset the effects of housing spillovers reaching the domestic market by adopting a more conservative policy, using as instruments the type of mortgage rate, the level of the maximum LTV ratios and the availability of MEW. Moreover, given the strong linkages across housing markets with strong bank foreign exposure, the results suggest that a closer monitoring of the bank flows across the countries should be of interest for policy makers and regulators. 


\section{Appendix}

\section{Table A.1: House price sources}

\begin{tabular}{|c|c|c|c|c|}
\hline Country & Code & Source & Coverage & Primary source \\
\hline Australia & $\mathrm{AU}$ & BIS & $\begin{array}{l}\text { Residential property prices, all detached } \\
\text { houses ( } 8 \text { cities), per dwelling }\end{array}$ & $\begin{array}{l}\text { Statistics Australia; Real Estate } \\
\text { Institute of Australia }\end{array}$ \\
\hline Austria & AT & BIS & $\begin{array}{l}\text { From } 1986 \text { Q4 onwards: residential property } \\
\text { prices, all dwellings in Vienna per sqm }\end{array}$ & Austrian Central Bank \\
\hline Belgium & $\mathrm{BE}$ & BIS & $\begin{array}{l}\text { Residential property prices, existing } \\
\text { dwellings, per dwelling }\end{array}$ & $\begin{array}{l}\text { Statistics Belgium; Stadim } \\
\text { Guide de valeurs immobiliers }\end{array}$ \\
\hline Canada & $\mathrm{CA}$ & BIS & National residential average price & $\begin{array}{l}\text { The Canadian Real Estate } \\
\text { Association; Multiple Listing } \\
\text { Service }\end{array}$ \\
\hline Denmark & DK & BIS & $\begin{array}{l}\text { Residential property prices, single-family } \\
\text { houses }\end{array}$ & Statistics Denmark \\
\hline Finland & FI & BIS & $\begin{array}{l}\text { Residential property prices, existing flats and } \\
\text { terraced houses, total, per sqm }\end{array}$ & Statistics Finland \\
\hline France & FR & BIS & $\begin{array}{l}\text { From } 1996 \text { Q1 onwards: Residential property } \\
\text { prices, existing dwellings; until } 1995 \text { Q4: } \\
\text { existing flats in Paris with suburbs }\end{array}$ & Statistics France \\
\hline Germany & $\mathrm{DE}$ & BIS & $\begin{array}{l}\text { Residential property prices, all owner- } \\
\text { occupied dwellings }\end{array}$ & $\begin{array}{l}\text { Statistics Germany, private } \\
\text { sector }\end{array}$ \\
\hline Greece & GR & $\begin{array}{l}\text { Oxford } \\
\text { Economics }\end{array}$ & n.a. & n.a. \\
\hline Ireland & IE & BIS & $\begin{array}{l}\text { From } 2005 \text { Q1 onwards: Residential property } \\
\text { prices, all dwellings; } 1970 \text { Q1-2004 Q4: Price } \\
\text { index, new houses }\end{array}$ & $\begin{array}{l}\text { Statistics Ireland; Department of } \\
\text { the Environment, Community } \\
\text { and Local Government }\end{array}$ \\
\hline Italy & IT & BIS & $\begin{array}{l}\text { From } 1990 \text { Q1 onwards: Residential property } \\
\text { prices, all dwellings; } 1971 \text { Q1-1989 Q4: Bank } \\
\text { of Italy historical residential property price } \\
\text { index }\end{array}$ & Banca d'Italia; Statistics Italy \\
\hline Netherlands & NL & BIS & $\begin{array}{l}\text { From } 1996 \text { Q1 onwards: Residential property } \\
\text { prices, all existing dwellings; From 1976 Q1- } \\
\text { 1995 Q4: Existing dwellings; 1970 Q1-1975 } \\
\text { Q4: Sales of houses and flats brokered by real } \\
\text { estate agents }\end{array}$ & $\begin{array}{l}\text { Statistics } \quad \text { Netherlands; } \\
\text { Nederlandse } \\
\text { Makelaars }\end{array}$ \\
\hline Spain & ES & BIS & $\begin{array}{l}\text { Residential property prices, all dwellings, per } \\
\text { sqm }\end{array}$ & $\begin{array}{l}\text { Banco de España; } \\
\text { Hipotecario; OECD }\end{array}$ \\
\hline Sweden & SE & BIS & $\begin{array}{l}\text { From } 1986 \text { Q1 onwards: Residential property } \\
\text { prices, all owner-occupied houses, per } \\
\text { dwelling; } 1970 \text { Q1-1985 Q4: Index of owner- } \\
\text { occupied one- and two-dwelling buildings }\end{array}$ & Statistics Sweden \\
\hline Switzerland & $\mathrm{CH}$ & BIS & $\begin{array}{l}\text { Non-weighted average of owner-occupied } \\
\text { flats and houses in the country as a whole }\end{array}$ & Swiss National Bank \\
\hline $\begin{array}{l}\text { United } \\
\text { Kingdom }\end{array}$ & UK & Nationwide & $\begin{array}{l}\text { House price information is from Nationwide } \\
\text { lending data for properties at the post survey } \\
\text { approval stage }\end{array}$ & Nationwide \\
\hline
\end{tabular}




United
States $\quad$ US $\begin{aligned} & \text { S\&P/Case } \\ & \begin{array}{l}\text { Shiller } \\ \text { index }\end{array}\end{aligned} \begin{aligned} & \text { Composite of single-family home price } \\ & \text { indices for the nine US Census divisions }\end{aligned} \quad$ S\&P/Case Shiller index

\section{Table A.2: Data sources and definitions}

\begin{tabular}{|c|c|c|}
\hline Variable & Source & Description \\
\hline Real house prices & See Table A1 & See Table A1 \\
\hline Real GDP & OECD & \\
\hline Credit-to-GDP ratio & BIS & $\begin{array}{l}\text { Credit from domestic banks to the private nonfinancial sector as } \\
\text { a share from GDP }\end{array}$ \\
\hline Inflation & OECD & CPI inflation rate \\
\hline Population & Oxford Economics & Total population \\
\hline $\begin{array}{l}\text { Population between } \\
20 \text { and } 44\end{array}$ & World Bank & $\begin{array}{l}\text { The population at the age between } 20 \text { and } 44 \text { year as a share of } \\
\text { total population }\end{array}$ \\
\hline Unemployment rate & OECD & \\
\hline
\end{tabular}

Mortgage rate $\quad$ ECB, national sources

Building permits

Exchange rate

Oil prices

Financial leverage

Bilateral trade flows

Bilateral FDI flows

Portfolio investment flows

Bank flows
Datastream

Datastream

Datastream

US Flow of Funds

Trade Statistics of the OECD

Foreign

Direct

Investment Statistics of the OECD

CPIS database of the IMF

BIS
From 2003 to 2012 we use the households borrowing costs for purchasing a new home from the European Central Bank (ECB) which are available for Austria, Belgium, Finland, France, Germany, Greece, Ireland, Italy, Netherlands and Spain. In order to interpolate the above data back to 1990, we use the mortgage rate collected from national statistical offices of above countries. For the remaining countries we also use the mortgage rate available from national sources. When mortgage rate data is not available, we use the ten-year government bond yield in those countries that have mixed-rate mortgage rates as predominant mortgage contracts. For countries where a variable mortgage rate is more widely used, we choose the one-year government bond yield instead.

Exchange rate vis-à-vis the US dollar

Price of crude oil

The sum of equity and total liabilities of US broker-dealers divided by their equity

Bilateral bank claims based on the consolidated bank statistics of the BIS using Table 9B 
The average of the trade and the investment openness which are sub-indices of the Index of Economic Freedom constructed by the Heritage Foundation

Table A.3: Full results for the alternative estimators and estimation with a time-unvarying weight matrix

\begin{tabular}{|c|c|c|c|}
\hline & $\begin{array}{l}\text { Model 6: } \\
\text { Bayesian } \\
\text { estimation }\end{array}$ & $\begin{array}{l}\text { Model 7: } \\
\text { IV estimation }\end{array}$ & $\begin{array}{l}\text { Model 10: } \\
\text { Time-unvarying } \\
\text { weight matrix }\end{array}$ \\
\hline$\rho$ & $\begin{array}{l}0.2619^{* * *} \\
(0.0258)\end{array}$ & $\begin{array}{l}0.3036^{* * *} \\
(0.0494)\end{array}$ & $\begin{array}{l}0.2438^{* * *} \\
(0.0391)\end{array}$ \\
\hline$\varphi$ & $\begin{array}{l}0.5523^{* * *} \\
(0.0199)\end{array}$ & $\begin{array}{l}0.4743^{* * *} \\
(0.0354)\end{array}$ & $\begin{array}{l}0.4837^{* * *} \\
(0.0226)\end{array}$ \\
\hline \multicolumn{4}{|l|}{$\beta$} \\
\hline Credit-to-GDP & $\begin{array}{l}0.0180^{* * *} \\
(0.0045)\end{array}$ & $\begin{array}{l}0.0212^{* * *} \\
(0.0060)\end{array}$ & $\begin{array}{l}0.0228^{* * *} \\
(0.0061)\end{array}$ \\
\hline Housing permits & $\begin{array}{l}0.0014 \\
(0.0021)\end{array}$ & $\begin{array}{l}0.0016 \\
(0.0034)\end{array}$ & $\begin{array}{l}0.0011 \\
(0.0027)\end{array}$ \\
\hline Population & $\begin{array}{l}1.7796^{* * *} \\
(0.3709)\end{array}$ & $\begin{array}{l}2.0211^{* * *} \\
(0.4954)\end{array}$ & $\begin{array}{l}2.0543^{* * *} \\
(0.4960)\end{array}$ \\
\hline Population 20-44 & $\begin{array}{l}0.5238^{* * *} \\
(0.2047)\end{array}$ & $\begin{array}{l}0.5437^{* * *} \\
(0.2585)\end{array}$ & $\begin{array}{l}0.4599^{* * *} \\
(0.2591)\end{array}$ \\
\hline GDP per capita & $\begin{array}{l}0.0949^{* * *} \\
(0.0349)\end{array}$ & $\begin{array}{l}0.1253^{* * *} \\
(0.0551)\end{array}$ & $\begin{array}{l}0.1307^{* * *} \\
(0.0426)\end{array}$ \\
\hline Unemployment & $\begin{array}{l}-0.0039^{* * *} \\
(0.0011)\end{array}$ & $\begin{array}{l}-0.0049^{* * *} \\
(0.0014)\end{array}$ & $\begin{array}{l}-0.0054^{* * *} \\
(0.0014)\end{array}$ \\
\hline Inflation & $\begin{array}{l}0.0733 \\
(0.0705)\end{array}$ & $\begin{array}{l}0.1122 \\
(0.0999)\end{array}$ & $\begin{array}{l}0.0999 \\
(0.0891)\end{array}$ \\
\hline Exchange rate & $\begin{array}{l}0.0024 \\
(0.0026)\end{array}$ & $\begin{array}{l}0.0006 \\
(0.0032)\end{array}$ & $\begin{array}{l}-0.0010 \\
(0.0034)\end{array}$ \\
\hline Mortgage rate & $\begin{array}{l}-0.0036^{* * *} \\
(0.0007)\end{array}$ & $\begin{array}{l}-0.0033^{* * *} \\
(0.0011)\end{array}$ & $\begin{array}{l}-0.0032^{* * *} \\
(0.0010)\end{array}$ \\
\hline$\lambda$ & & & \\
\hline Credit-to-GDP & $\begin{array}{l}0.0148 \\
(0.0125)\end{array}$ & $\begin{array}{l}0.0214 \\
(0.0149)\end{array}$ & $\begin{array}{l}-0.0013 \\
(0.0192)\end{array}$ \\
\hline Permits & $\begin{array}{l}0.0096^{*} \\
(0.0055)\end{array}$ & $\begin{array}{l}0.0055 \\
(0.0074)\end{array}$ & $\begin{array}{l}0.0025 \\
(0.0083)\end{array}$ \\
\hline Population & $\begin{array}{l}-2.9003^{* * *} \\
(1.0905)\end{array}$ & $\begin{array}{l}-4.8378^{* * *} \\
(1.4298)\end{array}$ & $\begin{array}{l}-4.2086^{* * *} \\
(1.8179)\end{array}$ \\
\hline Population 20-44 & 0.6794 & 0.9169 & $1.3064^{* * *}$ \\
\hline
\end{tabular}




\begin{tabular}{llll} 
& $(0.4189)$ & $(0.5852)$ & $(0.5264)$ \\
GDP per capita & -0.0543 & 0.0495 & 0.0238 \\
& $(0.0925)$ & $(0.1319)$ & $(0.1253)$ \\
Unemployment & 0.0040 & $0.0080^{* *}$ & $0.0074^{*}$ \\
& $(0.0027)$ & $(0.0040)$ & $(0.0038)$ \\
Inflation & $-0.4287^{* * *}$ & $-0.4534^{* * *}$ & $-0.5777^{* * *}$ \\
& $(0.1455)$ & $(0.2109)$ & $(0.1951)$ \\
Exchange rate & 0.0026 & 0.0069 & 0.0148 \\
& $(0.0053)$ & $(0.0067)$ & $(0.0093)$ \\
Mortgage rate & $-0.0027^{*}$ & -0.0015 & -0.0013 \\
$\gamma$ & $(0.0015)$ & $(0.0021)$ & $(0.0019)$ \\
& & & \\
Oil price & 0.0025 & 0.0031 & 0.0054 \\
Financial leverage & $(0.0032)$ & $(0.0035)$ & $(0.0033)$ \\
Country-specific & $(0.0004)$ & -0.0006 & -0.0001 \\
dummy & Yes & $(0.0004)$ & $(0.0004)$ \\
\hline LL & 4283.1 & Yes & Yes \\
MSE & 0.00023 & & 4303.3 \\
Adjusted R2 & & 0.00023 & 0.00022 \\
\hline & & 0.4713 & 0.4742 \\
\hline
\end{tabular}


Table A.4: Mortgage market indicators

\begin{tabular}{lllllll}
\hline & $\begin{array}{l}\text { Prevailing } \\
\text { mortgage } \\
\text { rate type } \\
\text { (variable 1, } \\
\text { fixed 0, } \\
\text { mixed 0.5) }\end{array}$ & $\begin{array}{l}\text { MEW } \\
\text { (Yes 1, No }\end{array}$ & $\begin{array}{l}\text { Maxi- } \\
\text { mum } \\
\text { LTV } \\
\text { ratio }\end{array}$ & $\begin{array}{l}\text { Ratio of } \\
\text { MBSs to } \\
\text { residential } \\
\text { loans }\end{array}$ & $\begin{array}{l}\text { Index of } \\
\text { govern- } \\
\text { ment } \\
\text { partici- } \\
\text { pation }\end{array}$ & $\begin{array}{l}\text { Index of } \\
\text { mortgage } \\
\text { market } \\
\text { development } \\
\text { (average } \\
\text { from all } \\
\text { indicators) }\end{array}$ \\
\hline AU & 1 & 1 & & & & 0.69 \\
AT & 0 & 0 & 0.95 & 0.167 & 0.31 & 0.20 \\
BE & 0 & 0 & 0.80 & 0.031 & 0.19 & 0.31 \\
CA & 0.5 & 1 & 0.80 & 0.299 & 0.25 & 0.61 \\
DK & 0.5 & 1 & 0.310 & 0.44 & 0.51 \\
FI & 1 & 1 & 1.00 & 0 & 0.25 & 0.66 \\
FR & 0 & 0 & 1.00 & 0.018 & 0.31 & 0.27 \\
DE & 0 & 0 & 0.80 & 0.018 & 0.25 & 0.21 \\
GR & 1 & 0 & 0.80 & 0 & 0.29 & 0.42 \\
IR & 1 & 1 & 1.00 & 0.296 & 0.25 & 0.71 \\
IT & 0.5 & 0 & 0.80 & 0.308 & 0.25 & 0.37 \\
NL & 0 & 1 & 1.25 & 0.308 & 0.5 & 0.61 \\
ES & 1 & 0 & 1.00 & 0.241 & 0.31 & 0.51 \\
SE & 1 & 1 & 0.85 & 0.003 & 0.29 & 0.63 \\
CH & 0.5 & 0 & 0.80 & 0.180 & 0.29 & 0.35 \\
UK & 1 & 1 & 1.10 & 0.312 & 0.13 & 0.71 \\
US & 0 & 1 & 1.00 & 0.641 & 0.56 & 0.64 \\
\hline Source: & Warnock and Warnock (2008), IMF (2011), European & Mortgage Federation (2014)
\end{tabular}




\section{Figure A.1: Quarterly house price growth rate}

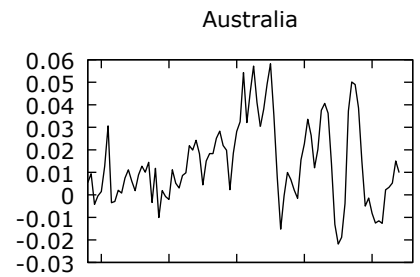

19911996200120062011
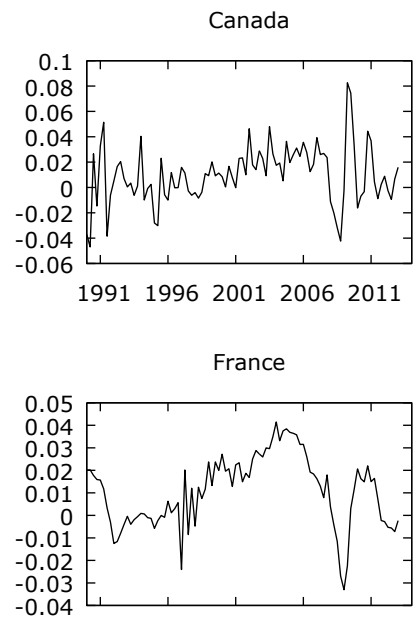

19911996200120062011

Ireland

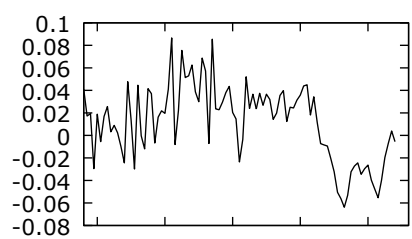

19911996200120062011

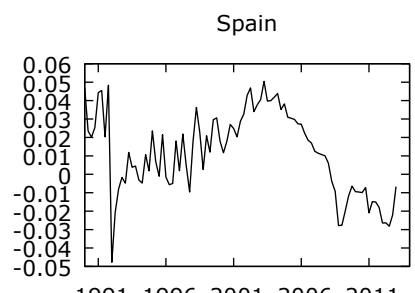

19911996200120062011

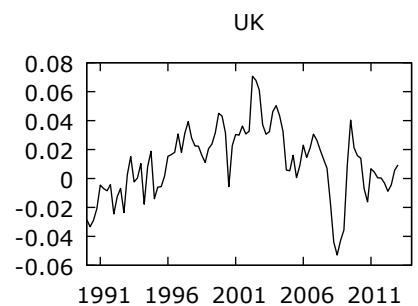

Source: See Table A.1

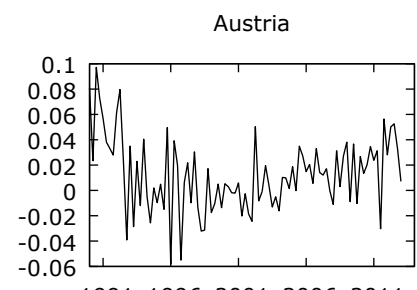

19911996200120062011

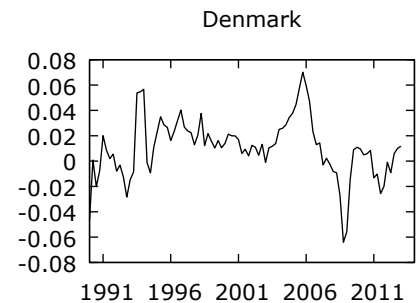

Germany
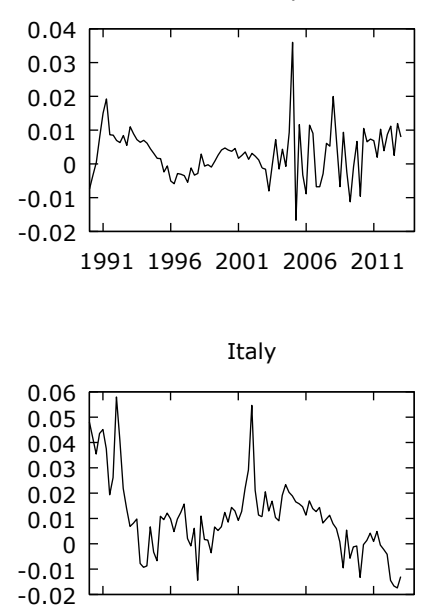

19911996200120062011

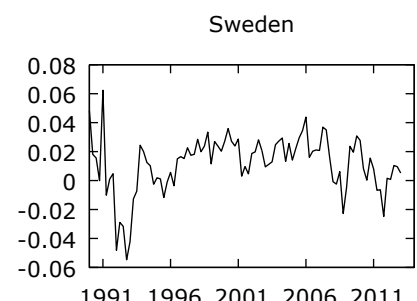

US

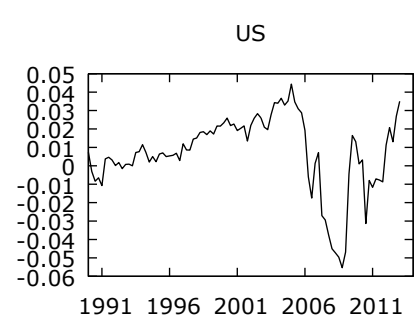

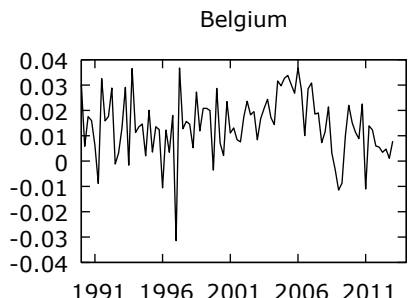

Finland

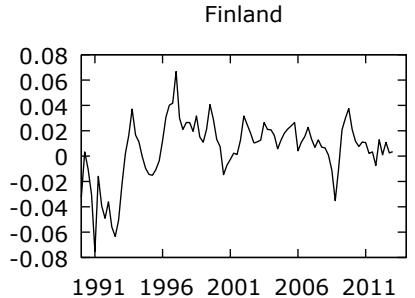

Greece

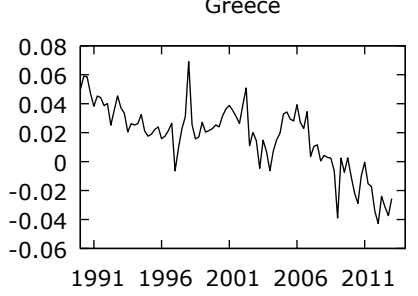

Netherlands

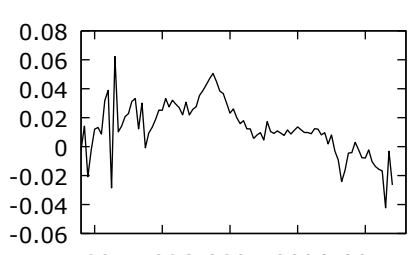

19911996200120062011

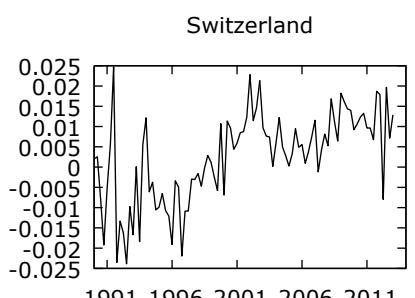

19911996200120062011 
Figure A.2: Average bilateral bank (asset-side, liability-side) exposure of US, UK and Germany to selected countries between 1999 and 2012

US

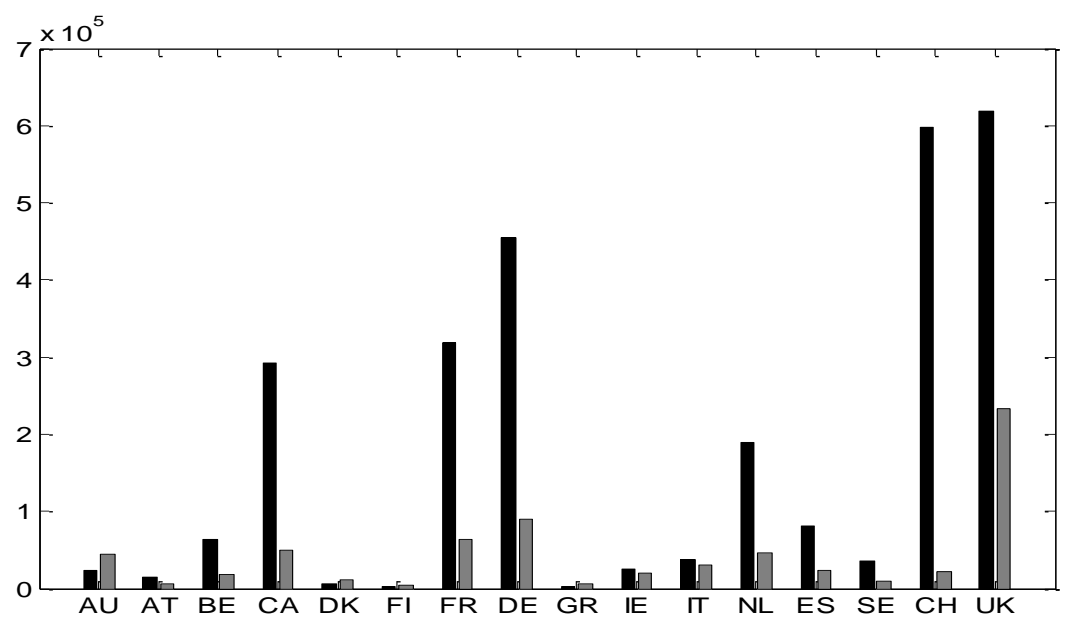

UK

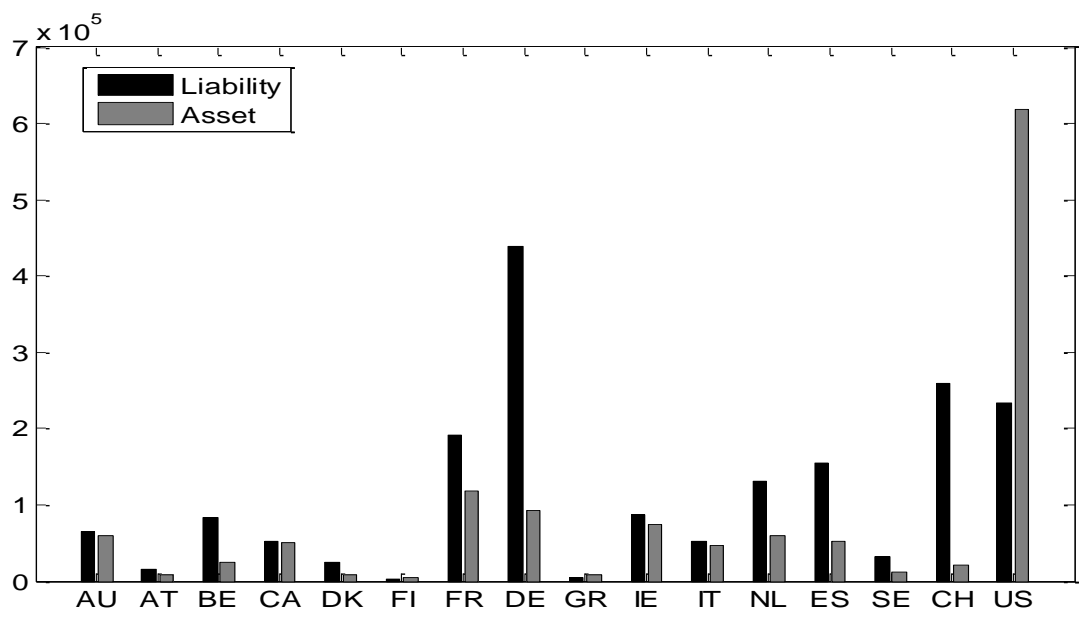

Germany

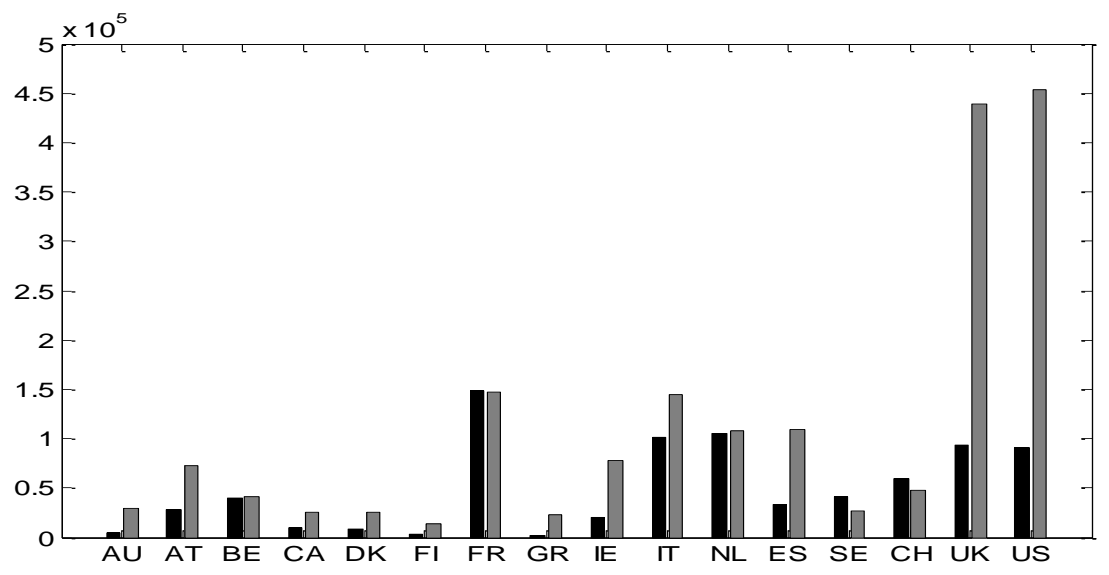

Source: BIS. Consolidated bank flows, immediate borrower basis in millions of US dollars. 
Figure A.3: The spatio-temporal effects on global housing returns stemming from a country-specific housing shock

Figure A.3-a: Spatio-Temporal Dimension

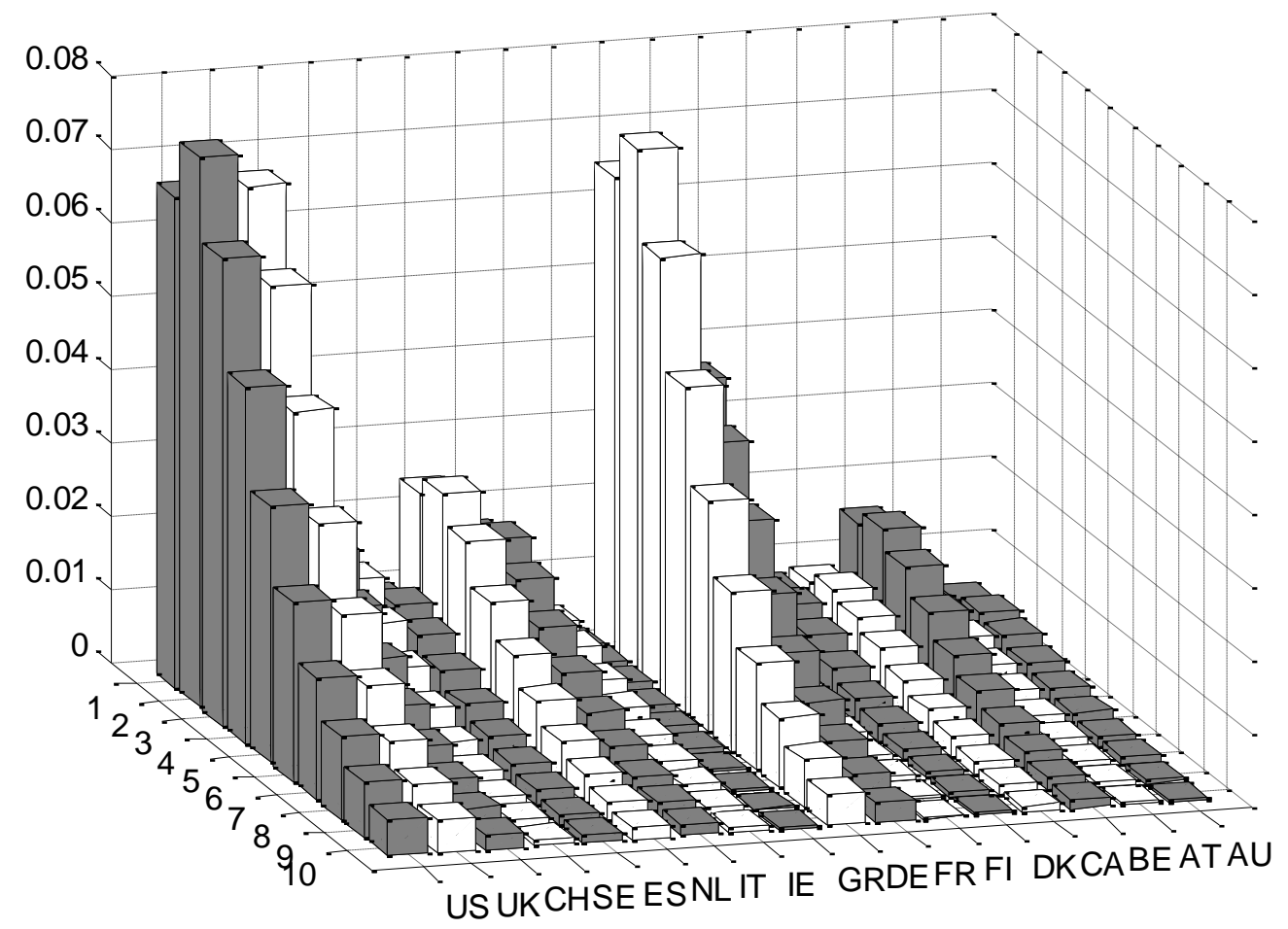

Figure A.3-b: Spatial Dimension

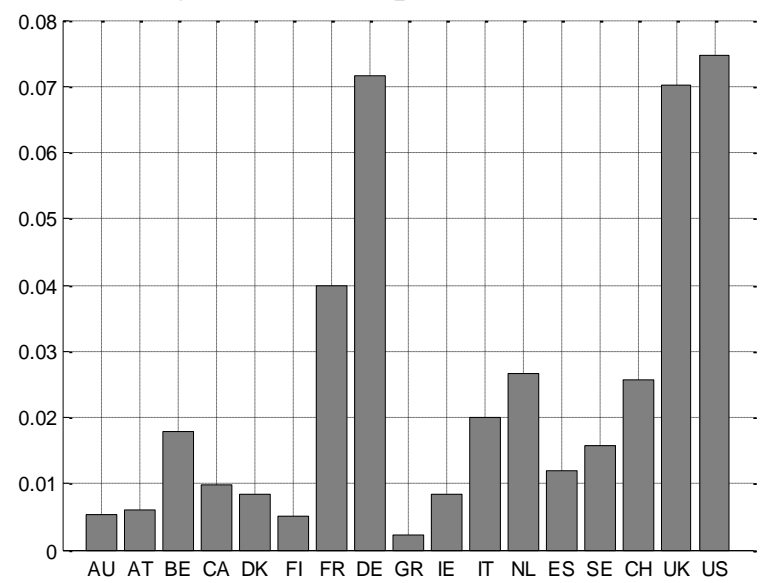

Figure A.3-c: Time Dimension

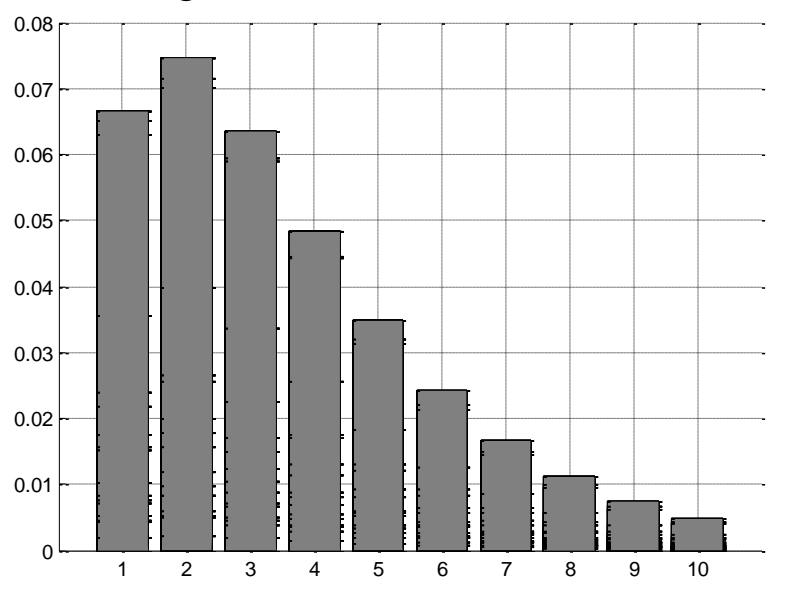


Figure A.4: The spatial effect in the second quarter after a shock increasing US, UK or German housing returns on housing returns in individual countries
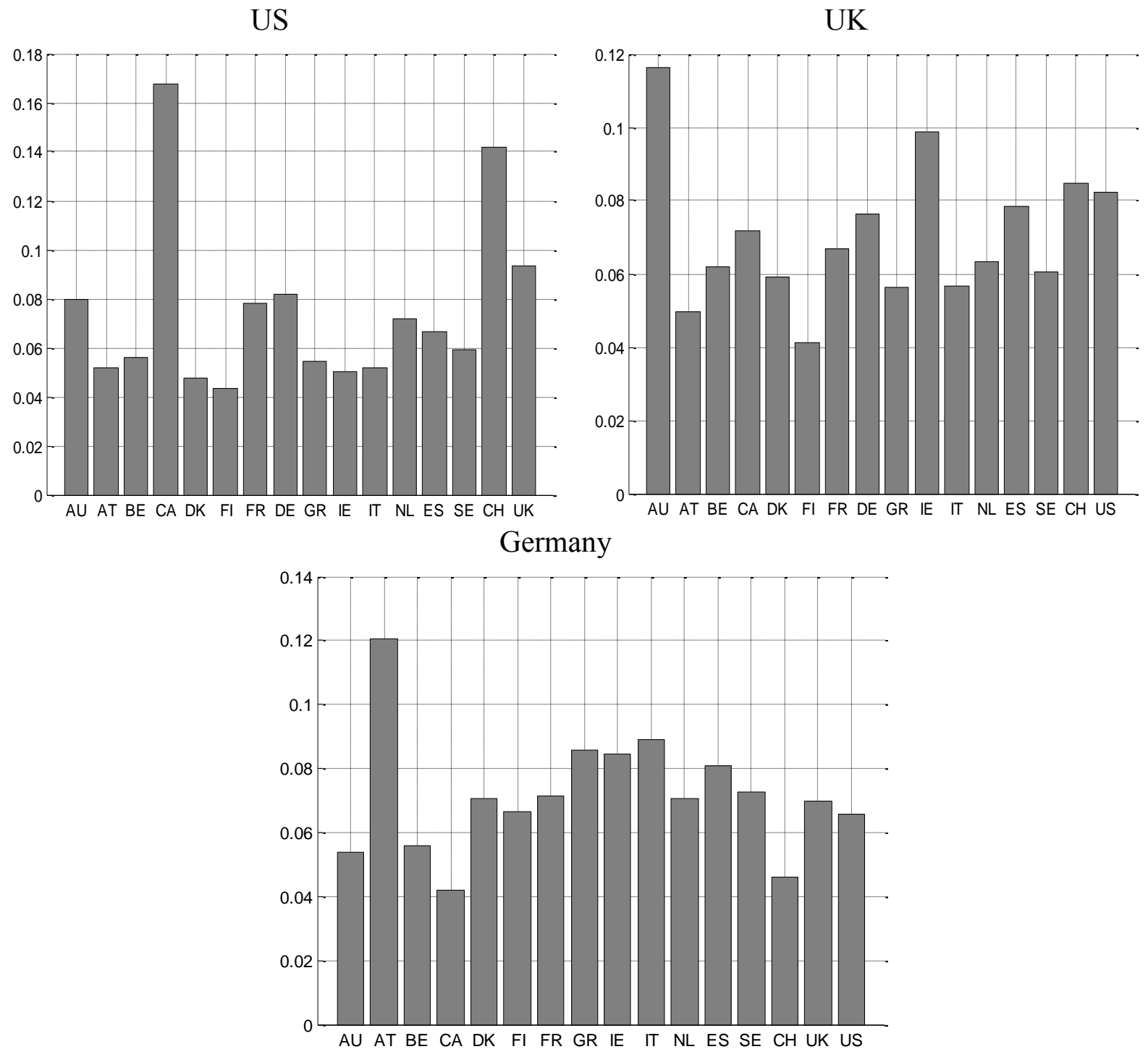
Figure A.5: The average response of housing returns in the second quarter in each country following a foreign housing shock - a comparison between the baseline model (black) and a model with mortgage market variables (grey)

Overall mortgage market development

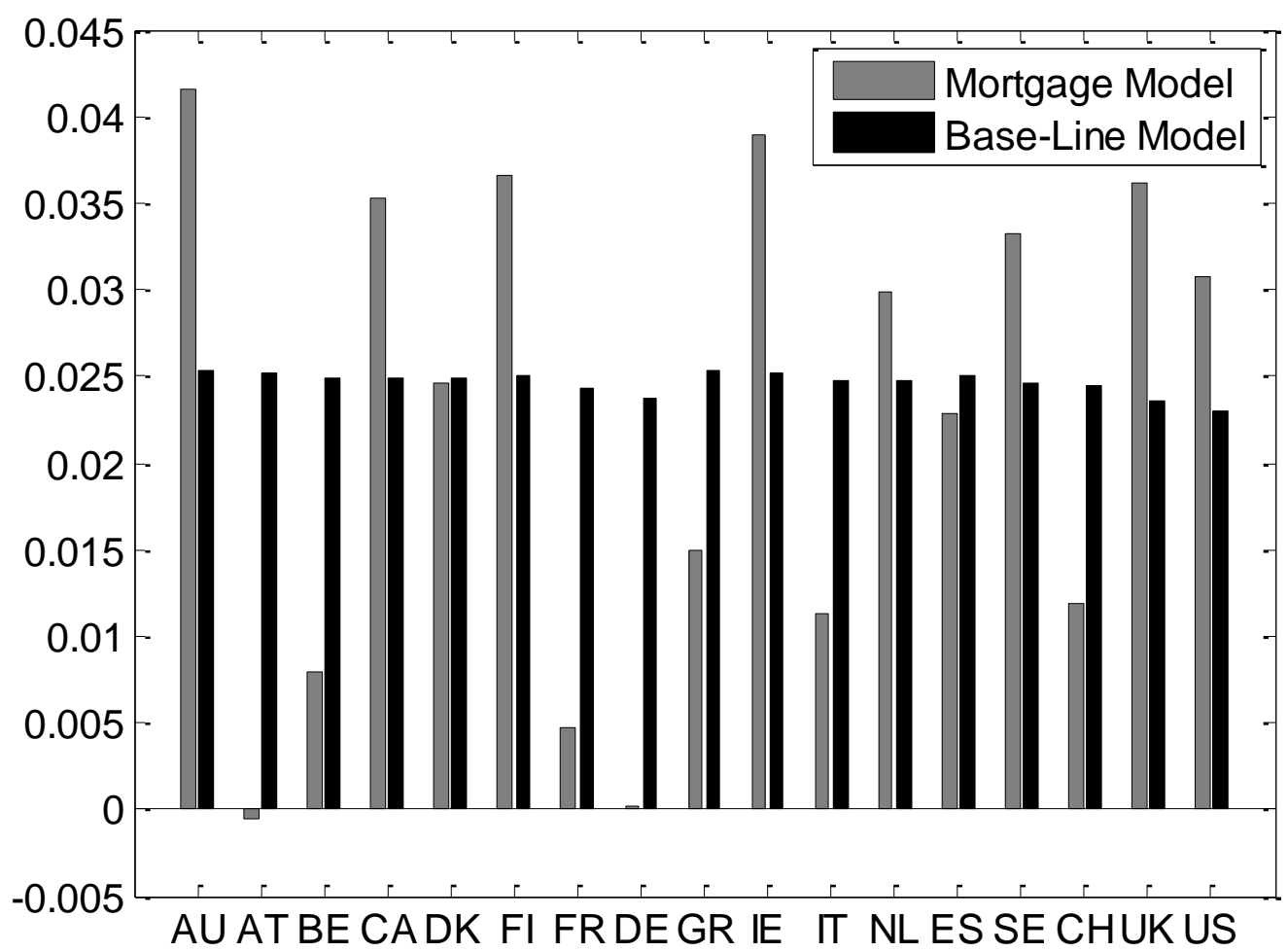

Type of prevailing mortage rate

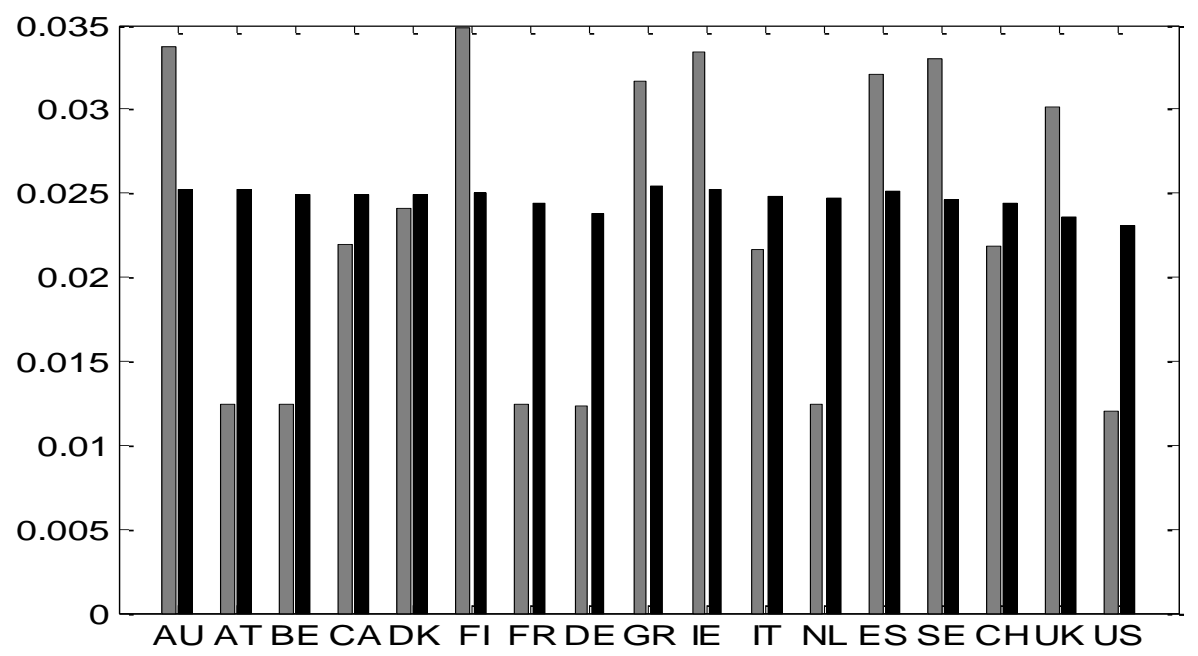


MEW

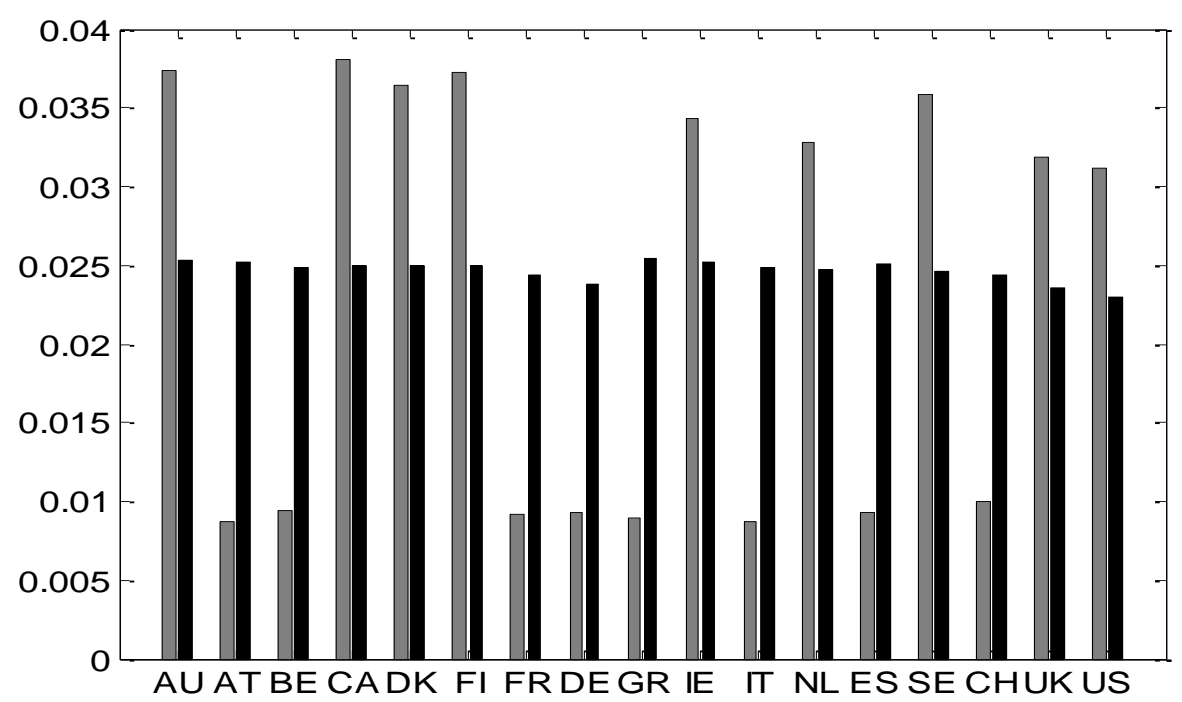

Maximum LTV ratio

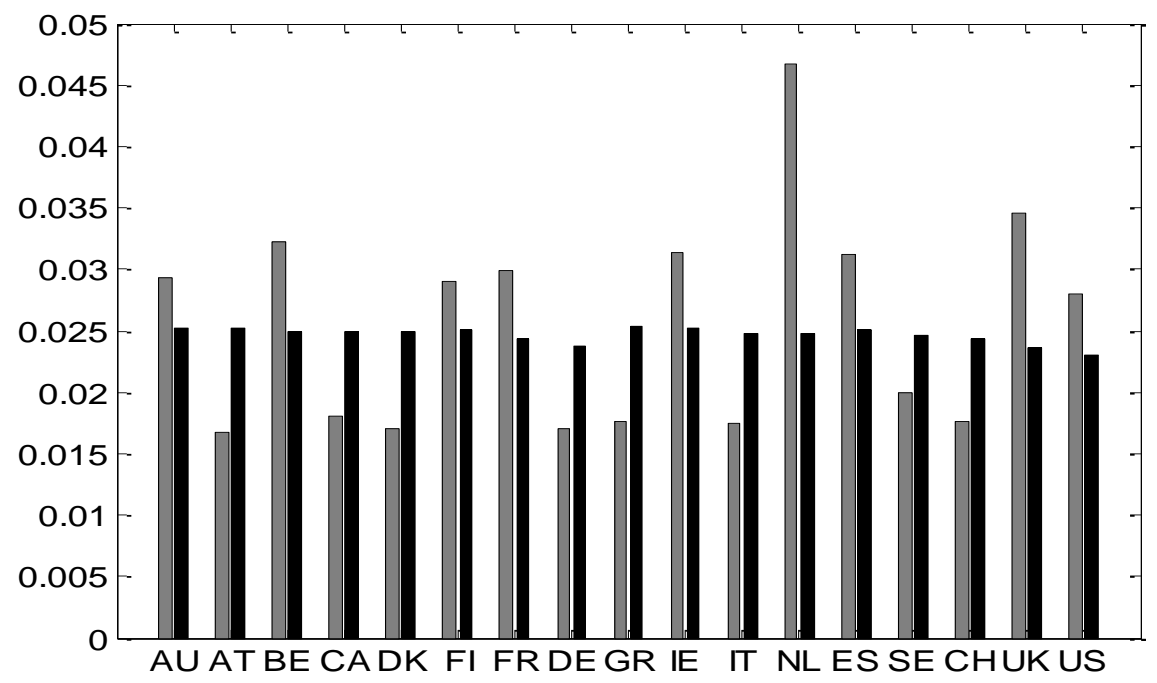


Figure A.6: The response of housing returns in the second quarter in US, UK or Germany to a country-specific housing shock - a comparison between the baseline model (black) and a model with mortgage market development (grey)

US

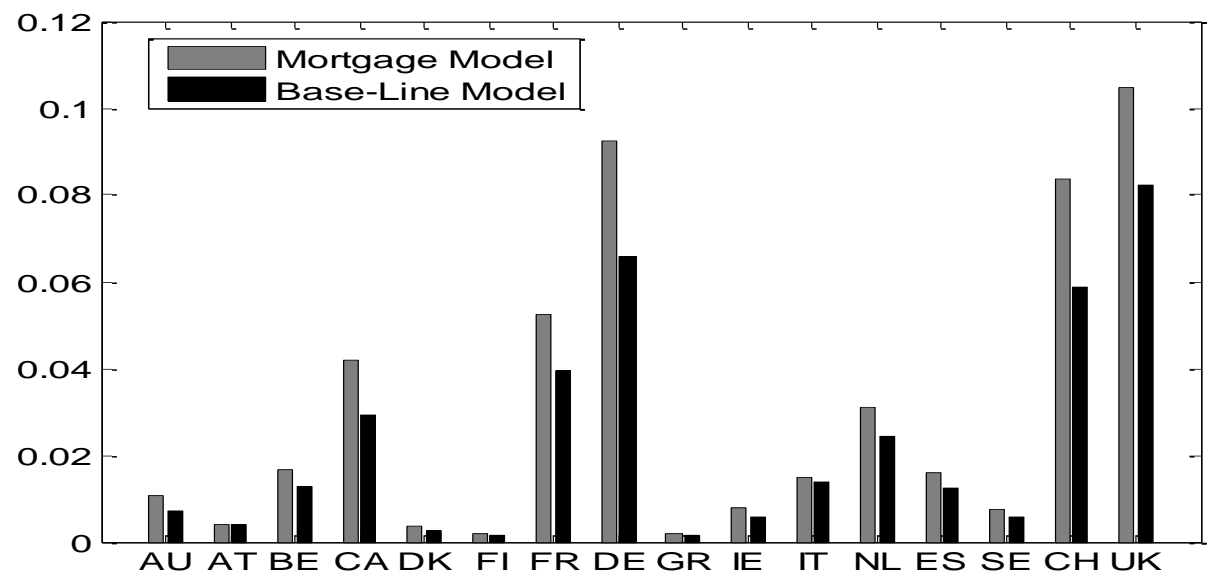

UK

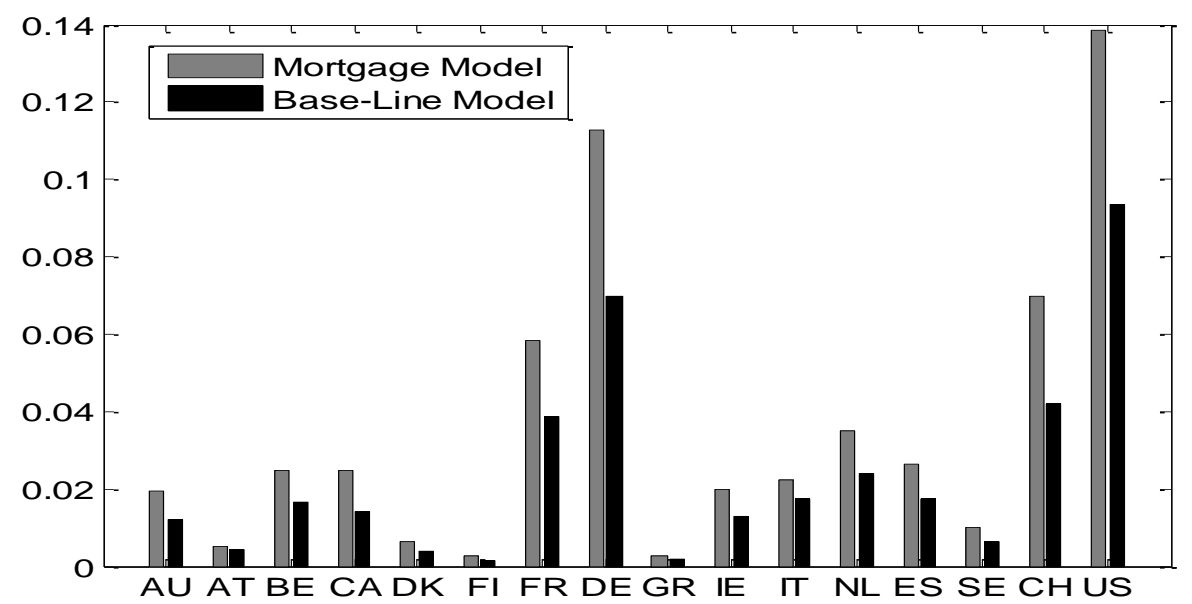

Germany

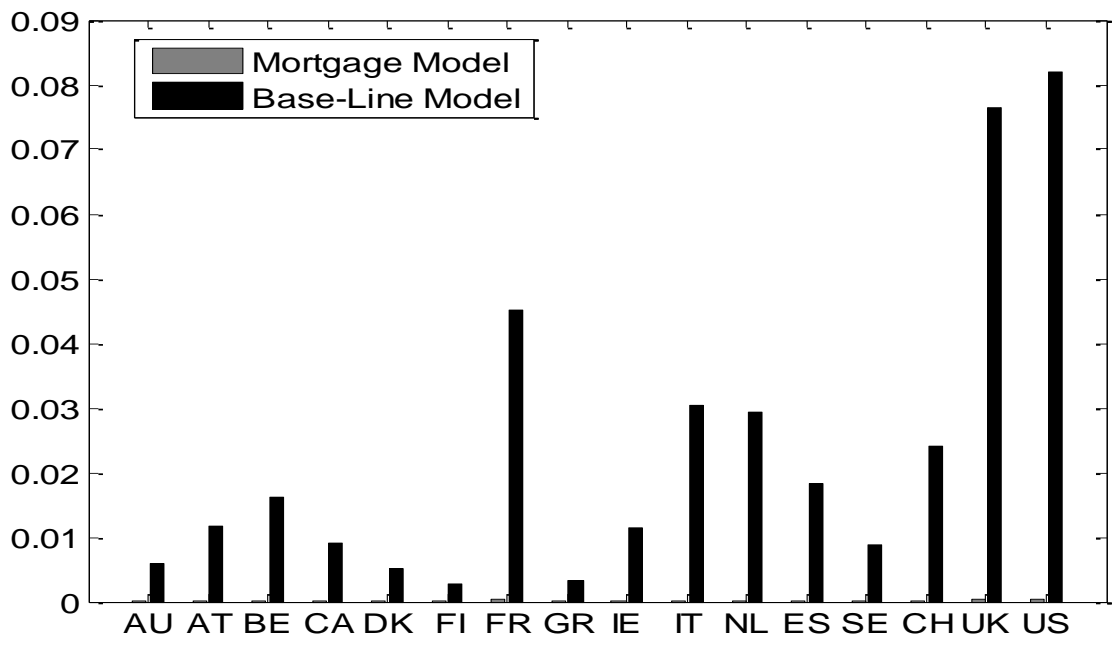




\section{References}

Adrian, T. and H. S. Shin. 2010. Liquidity and leverage. Journal of Financial Intermediation 19, $418-437$.

Aizenman, J. and Y. Jinjarak. 2009. Current account patterns and national real estate markets. Journal of Urban Economics 66(2), 75-89.

Allen, F., T. Beck, E. Carletti, P. R. Lane, D. Schoenmaker and W. Wagner. 2011. Cross-border banking in Europe: Implications for financial stability and macroeconomic policies. CEPR Report.

Altunbas, Y., L. Gambacorta and D. Marques-Ibanez. 2009. Securitisation and the bank lending channel. European Economic Review 53(8), 996-1009.

Anselin, L. 2006. Spatial econometrics. In: Mills, T. C., Patterson, K. (Eds.), Palgrave Handbook of Econometrics, Econometric Theory, Vol. 1. Palgrave Macmillan, Basingstoke, 901-969.

Aron, J., J. V. Duca, J. Muellbauer, K. Murata and A. Murphy. 2012. Credit, housing collateral, and consumption: Evidence from Japan, the UK, and the US. Review of Income and Wealth 58(3), 397-423.

Asgharian, H. and C. Bengtsson. 2006. Jump spillover in international equity markets. Journal of Financial Econometrics 4, 167-203.

Asgharian, H. and M. Nossman. 2011. Risk contagion among international stock markets. Journal of International Money and Finance 28, 22-38.

Asgharian, H., W. Hess and L. Liu. 2013. A spatial analysis of international stock market linkages. Journal of Banking and Finance 37, 4738-4754. 
Bagliano, F. C. and C. Morana. 2012. The great recession: US dynamics and spillovers to the world economy. Journal of Banking and Finance 36, 1-13.

Bank for International Settlements. 2010. Funding patterns and liquidity management of internationally active banks. Committee on the Global Financial System Paper 39.

Bank of England. 2013. Cross-border bank credit and global financial stability. Quarterly bulletin Q2.

Beenstock, M. and D. Felsenstein. 2007. Spatial vector autoregressions. Spatial Economic Analysis 2, 167-196.

Beine, M., A. Cosma and R. Vermeulen. 2010. The dark side of global integration: Increasing tail dependence. Journal of Banking and Finance 34, 184-192.

Bekaert, G., M. Ehrmann, M. Fratzscher and A. Mehl. 2014. The global crisis and equity market contagion. Journal of Finance 69(6), 2597-2649.

Beltratti, A. and C. Morana. 2010. International house prices and macroeconomic fluctuations. Journal of Banking and Finance 34, 533-545.

Beltratti, A. and R. M. Stulz. 2012. The credit crisis around the globe: Why did some banks perform better? Journal of Financial Economics 105, 1-17.

Borio, C. and P. Disyatat. 2011. Global imbalances and the financial crisis: Link or no link? BIS Working Paper 346.

Bruno, V. and H. S. Shin. 2014. Cross-border banking and global liquidity. Princeton University Working Paper. 
Calomiris, C., I. Love and M. S. Martinez Peria. 2012. Stock returns' sensitivities to crisis shocks: Evidence from developed and emerging markets. Journal of International Money and Finance 31, 743-765.

Calza, A., T. Monacelli and L. Stracca. 2013. Housing finance and monetary policy. Journal of the European Economic Association 11(supplement), 101-122. DOI:10.1111/j.15424774.2012.01095

Carstensen, K., O. Heulsewig and T. Wollmersheauser. 2009. Monetary policy transmission and house prices: European cross-country evidence. Technical Report.

Cesa-Bianchi, A. 2013. Housing cycles and macroeconomic fluctuations: A global perspective. Journal of International Money and Finance 37, 215-238.

Cetorelli, N. and L. S. Goldberg. 2011. Global banks and international shock transmission: Evidence from the crisis. IMF Economic Review 59(1), 41-76.

Cetorelli, N. and L. S. Goldberg. 2012a. Liquidity management of US global banks: Internal capital markets in the great recession. Journal of International Economics 88, 299-311.

Cetorelli, N. and L. S. Goldberg. 2012b. Banking globalization and monetary transmission. Journal of Finance 67(5), 1811-1843.

Chinn, M. D. and K. J. Forbes. 2004. A decomposition of global linkages in financial markets over time. The Review of Economics and Statistics 86(3), 705-722.

Clapp, J. M., W. Dolde and D. Tirtiroglu. 1995. Imperfect information and investor inferences from housing price dynamics. Real Estate Economics 23(3), 239-269. 
Conley, T. G. and G. Topa. 2002. Socio-economic distance and spatial patterns in unemployment. Journal of Applied Econometrics 17, 303-327.

Duca, J. V., J. Muellbauer and A. Murphy. 2011. House prices and credit constraints: Making sense of the US experience. The Economic Journal 121, 533-551.

Eickmeier, S., L. Gambacota and B. Hofmann. 2014. Understanding global liquidity. European Economic Review 68, 1-18.

Eickmeier, S. and T. Ng. 2011. How do credit supply shocks propagate internationally? A GVAR approach. CEPR Discussion Paper 8720.

Elhorst, J. P. 2014. Spatial Econometrics: From Cross-sectional Data to Spatial Panels. Springer, Heidelberg, New York, Dordrecht, London.

European Central Bank. 2009. Housing finance in the Euro Area. Occasional Paper Series 101.

European Mortgage Federation. 2014. Hypostat 2014. EMF.

Fernandez-Aviles, G., J. M. Montero and A. Orlov. 2012. Spatial modeling of stock market comovements. Finance Research Letters 9, 202-212.

Forbes, K. J. and F. E. Warnock. 2012. Capital flow waves: Surges, stops, flight and retrenchment. Journal of International Economics 88(2), 235-251.

Gourinchas, P-O. and M. Obstfeld. 2012. Stories of the twentieth century for the twenty-first. American Economic Journal: Macroeconomics 4(1), 226-265.

Gupta, R. and S. M. Miller. 2012. The time-series properties of housing prices: A case study of the Southern California market. Journal of Real Estate Finance and Economics 44(3), 339-361. 
Hirata, H., M. A. Kose, C. Otrok and M. Terrones. 2013. Global house price fluctuations: Synchronization and determinants. IMF Working Paper 38.

Holly, S., M. H. Pesaran and T. Yamagata. 2011. The spatial and temporal diffusion of house prices in the UK. Journal of Urban Economics 69, 2-23.

Iacoviello, M. 2005. House prices, borrowing constraints, and monetary policy in the business cycle. American Economic Review 95(3), 739-764.

International Monetary Fund. 2008. The changing housing cycle and its implications for monetary policy. World Economic Outlook, April.

International Monetary Fund. 2011. Global Financial Stability Report, April.

Ivashina, V., D. Schaftstein and J. Stein. 2012. Dollar funding and the lending behavior of global banks. NBER Working Paper 18528.

Kapan, T. and C. Minoiu. 2013. Balance sheet strength and bank lending during the global financial crisis. International Monetary Fund Working Paper 102, May.

Karolyi, G. A. and R. M. Stulz. 1996. Why do markets move together? An investigation of USJapan stock return co-movements. Journal of Finance 51, 951-986.

Kelejian, H. H. and I. R. Prucha, 1998. A generalized spatial two-stage least squares procedure for estimating a spatial autoregressive model with autoregressive disturbance. Journal of Real Estate Finance and Economics 17(1), 99-121.

Kelejian, H., G. Tavlas, G. Hondroyiannis. 2006. A spatial modelling approach to contagion among emerging economies. Open Economies Review 17 (4/5), 423-443. 
Landier, A., D. Sraer and D. Thesmar. 2013. Banking integration and house price co-movement. SSRN Working Paper, http://papers.ssrn.com/sol3/papers.cfm?abstract id=2347315. [Accessed 3 June 2015].

Lane, P. R. and B. Pels. 2012. Current account imbalances in Europe. CEPR Discussion Paper 8958.

Lane, P. R. and P. McQuade. 2014. Domestic credit growth and international capital flows. The Scandinavian Journal of Economics 116(1), 218-252.

Lane, P. R. and G. M. Milesi-Ferretti. 2008. The drivers of financial globalization. American Economic Review 98(2), 327-332.

LeSage, J. P. 2010. Econometrics Toolbox. http://www.spatial-econometrics.com/. [Accessed 3 June 2015].

LeSage, J. and R. K. Pace. 2009. Introduction to Spatial Econometrics. Chapman \& Hall/CRC, Boca Raton.

Loutskina, E. and P. Strahan. 2011. Informed and uninformed investment in housing: The downside of diversification. Review of Financial Studies 24(5), 1447-1480.

Loutskina, E. and P. Strahan. 2012. Financial integration, housing and economic volatility. SSRN Working Paper, http://papers.ssrn.com/sol3/papers.cfm?abstract_id=1991430. [Accessed 3 June 2015].

Marston, R. C. 1997. International Financial Integration: A Study of Interest Differentials between the Major Industrial Countries. Cambridge University Press. 
McCarthy, Y. and K. McQuinn. 2013. Credit conditions in a boom and bust property market. Central Bank of Ireland Research Technical Paper 8/RT/13.

McGuire, P. and N. Tarashev. 2007. Global monitoring with the BIS international banking statistics. In: Bank for International Settlements (Ed.), Research on Global Financial Stability: The Use of BIS International Financial Statistics 29, 176-204. Bank for International Settlements.

Mendicino, C. and M. T. Punzi. 2014. House prices, capital inflows and macroprudential policy. Journal of Banking and Finance 49, 337-355.

Miao, H., S. Ramchander and M. C. Simpson. 2011. Return and volatility transmission in US housing markets. Real Estate Economics 39(4), 701-741.

Milcheva, S. 2013. Cross-country effects of regulatory capital arbitrage. Journal of Banking and Finance 37, 5329-5345.

Muellbauer, J. and A. Murphy. 1997. Booms and busts in the UK housing market. The Economic Journal 107(445), 1701-1727.

Musso, A., S. Neri and L. Stracca. 2011. Housing, consumption and monetary policy - How different are the US and the euro area? Journal of Banking and Finance 35, 3019-3041.

Obstfeld, M. 2012a. Financial flows, financial crises, and global imbalances. Journal of International Money and Finance 31, 469-480.

Obstfeld, M. 2012b. Does the current account still matter? American Economic Review 102(3), $1-23$. 
Organisation for Economic Co-operation and Development. 2011. Doing better for families. OECD. http://www.oecd.org/social/soc/doingbetterforfamilies.htm. [Accessed 3 June 2015].

Organisation for Economic Co-operation and Development. 2001. House prices and economic activity. OECD Economics Department Working Paper 279.

Peek, J. and E. Rosengren. 2000. Collateral damage: The effect of the Japanese banking crisis on real activity in the United States. American Economic Review 90(1), 34-45.

Pesaran, M. H. and Y. Shin. 1998. Generalized impulse response analysis in linear multivariate models. Economic Letters 58(1), 17-29.

Pesaran, M. H., T. Schuermann and S. Weiner. 2004. Modelling regional interdependencies using a global error-correcting macroeconometric model. Journal of Business and Economics Statistics $22,129-162$.

Poterba, J. M. 1984. Tax Subsidies to owner-occupied housing: An asset-market approach. Quarterly Journal of Economics 99, 729-752.

Pukthuanthong, K. and R. Roll. 2009. Global market integration: An alternative measure and its application. Journal of Financial Economics 94, 214-232.

Rajan, U., A. Seru and V. Vig. 2010. The failure of models that predict failure: Distance, $\begin{array}{llll}\text { incentives and } \text { default. WSRN } & \text { Working }\end{array}$ http://papers.ssrn.com/sol3/papers.cfm?abstract_id=1296982. [Accessed 3 June 2015].

Rey, H. 2013. Dilemma not trilemma: The global financial cycle and monetary policy independence. Proceedings of the Federal Reserve Bank of Kansas City Economic Symposium at Jackson Hole. 
Rubio, M. and J. Carrasco-Gallego. 2014. Macroprudential and monetary policies: Implications for financial stability and welfare. Journal of Banking and Finance 49, 326-336.

Sa, F., P. Towbin and T. Wieladek. 2013. Capital inflows, financial structure and housing booms. Journal of the European Economic Association 12(2), 522-546.

Schularick, M. and A. M. Taylor. 2012. Credit booms gone bust: monetary policy, leverage cycles, and financial crises, 1870-2008. American Economic Review 102, 1029-1061.

Shin, H. S. 2012. Global banking glut and loan risk premium. Mundell-Fleming Lecture. IMF Economic Review 60(2), 155-192.

Schnabl, P. 2012. International transmission of bank liquidity shocks: Evidence from an emerging market. Journal of Finance 67, 897-932.

The Heritage Foundation. 2014. The 2014 Index of Economic Freedom, http://www.heritage.org/index/about. [Accessed 3 June 2015].

Tong, H. and S-J. Wei. 2011. The composition matters: Capital inflows and liquidity crunch during a global economic crisis. Review of Financial Studies 24, 2023-2052.

Tsatsaronis, K. and H. Zhu. 2004. What drives house price dynamics: Cross-country evidence. BIS Quarterly Review, March.

Vansteenkiste, I. and P. Hiebert. 2011. Do house price developments spillover across euro area countries? Evidence from a global VAR. Journal of Housing Economics 20(4), 299-314.

Wälti, S. 2010. Stock market synchronization and monetary integration. Journal of International Money and Finance 30, 96-110. 
Warnock, V. C. and F. E. Warnock. 2008. Markets and housing finance. Journal of Housing Economics 17(3), 239-251.

Yu, J., R. de Jong and L. Lee 2008. Quasi-maximum likelihood estimators for spatial dynamic panel data with fixed effects when both $\mathrm{n}$ and $\mathrm{T}$ are large. Journal of Econometrics 146, 118-134.

Zhu, B., R. Fuess and N. Rottke. 2013. Spatial linkages in returns and volatilities among US regional housing markets. Real Estate Economics 41(1), 29-64. 